\title{
Contribution of fungi to primary biogenic aerosols in the atmosphere: wet and dry discharged spores, carbohydrates, and inorganic ions
}

\author{
W. Elbert ${ }^{1}$, P. E. Taylor ${ }^{2,3}$, M. O. Andreae ${ }^{1}$, and U. Pöschl ${ }^{1}$ \\ ${ }^{1}$ Max Planck Institute for Chemistry, Biogeochemistry Department, PO Box 3060, 55020 Mainz, Germany \\ ${ }^{2}$ Chemistry and Chemical Engineering, California Institute of Technology, Pasadena, CA 91125, USA \\ ${ }^{3}$ Centre for Cellular and Molecular Biology, School of Life and Environmental Sciences, Deakin University, 221 Burwood \\ Highway, Burwood, Victoria, 3125, Australia
}

Received: 20 September 2006 - Published in Atmos. Chem. Phys. Discuss.: 15 November 2006

Revised: 17 August 2007 - Accepted: 28 August 2007 - Published: 7 September 2007

\begin{abstract}
Biogenic aerosols play important roles in atmospheric chemistry physics, the biosphere, climate, and public health. Here, we show that fungi which actively discharge their spores with liquids into the air, in particular actively wet spore discharging Ascomycota (AAM) and actively wet spore discharging Basidiomycota (ABM), are a major source of primary biogenic aerosol particles and components. We present the first estimates for the global average emission rates of fungal spores.
\end{abstract}

Measurement results and budget calculations based on investigations in Amazonia (Balbina, Brazil, July 2001) indicate that the spores of AAM and ABM may account for a large proportion of coarse particulate matter in tropical rainforest regions during the wet season $\left(0.7-2.3 \mu \mathrm{g} \mathrm{m}^{-3}\right)$. For the particle diameter range of $1-10 \mu \mathrm{m}$, the estimated proportions are $\sim 25 \%$ during day-time, $\sim 45 \%$ at night, and $\sim 35 \%$ on average. For the sugar alcohol mannitol, the budget calculations indicate that it is suitable for use as a molecular tracer for actively wet discharged basidiospores (ABS). $\mathrm{ABM}$ emissions seem to account for most of the atmospheric abundance of mannitol (10-68 $\left.\mathrm{ng} \mathrm{m}^{-3}\right)$, and can explain the observed diurnal cycle (higher abundance at night). ABM emissions of hexose carbohydrates might also account for a significant proportion of glucose and fructose in air particulate matter $\left(7-49 \mathrm{ng} \mathrm{m}^{-3}\right)$, but the literature-derived ratios are not consistent with the observed diurnal cycle (lower abundance at night). AAM emissions appear to account for a large proportion of potassium in air particulate matter over tropical rainforest regions during the wet season (17-43 $\mathrm{ng} \mathrm{m}^{-3}$ ), and they can also explain the observed diurnal cycle (higher abundance at night). The results of our investigations and budget calculations for tropical rainfor-

Correspondence to: $\mathrm{W}$. Elbert

(elbert@mpch-mainz.mpg.de) est aerosols are consistent with measurements performed at other locations.

Based on the average abundance of mannitol reported for extratropical continental boundary layer air $\left(\sim 25 \mathrm{ng} \mathrm{m}^{-3}\right)$, we have also calculated a value of $\sim 17 \mathrm{Tg} \mathrm{yr}^{-1}$ as a first estimate for the global average emission rate of ABS over land surfaces, which is consistent with the typically observed concentrations of ABS $\left(\sim 10^{3}-10^{4} \mathrm{~m}^{-3} ; \sim 0.1-1 \mu \mathrm{g} \mathrm{m}^{-3}\right)$. The global average atmospheric abundance and emission rate of total fungal spores, including wet and dry discharged species, are estimated to be higher by a factor of about three, i.e. $\sim 1 \mu \mathrm{g} \mathrm{m}^{-3}$ and $\sim 50 \mathrm{Tg} \mathrm{yr}^{-1}$. Comparisons with estimated rates of emission and formation of other major types of organic aerosol $\left(\sim 47 \mathrm{Tg} \mathrm{yr}^{-1}\right.$ of anthropogenic primary organic aerosol; $12-70 \mathrm{Tg} \mathrm{yr}^{-1}$ of secondary organic aerosol) indicate that emissions from fungi should be taken into account as a significant global source of organic aerosol. The effects of fungal spores and related chemical components might be particularly important in tropical regions, where both physicochemical processes in the atmosphere and biological activity at the Earth's surface are particularly intense, and where the abundance of fungal spores and related chemical compounds are typically higher than in extratropical regions.

\section{Introduction}

Biogenic aerosols are ubiquitous in the Earth's atmosphere and they influence atmospheric chemistry and physics, the biosphere, climate, and public health. They play an important role in the spread of biological organisms and reproductive materials, and they can cause or enhance human, animal, and plant diseases. Moreover, they influence the Earth's energy budget by scattering and absorbing radiation, and they

Published by Copernicus Publications on behalf of the European Geosciences Union. 
can initiate the formation of clouds and precipitation as cloud condensation and ice nuclei (Dingle, 1966; Schnell and Vali, 1972; Cox and Wathes, 1995; Andreae and Crutzen, 1997; Hamilton and Lenton, 1998; Andreae et al., 2002; Ariya and Amyot, 2004; Taylor and Jonsson, 2004; Jaenicke, 2005; Lohmann and Feichter, 2005; Pöschl, 2005; Dusek et al., 2006; McFiggans et al., 2006; Sun and Ariya, 2006; and references therein). The composition, abundance, and origin of biogenic aerosol particles and components are, however, still poorly understood and quantified.

Primary biogenic aerosol (PBA) particles and components are emitted directly from the biosphere to the atmosphere. Examples of PBA particles are pollen, bacteria, fungal and fern spores, viruses, and fragments of animals and plants ( $\mathrm{Si}$ moneit and Mazurek, 1982; Matthias-Maser and Jaenicke, 1992; Artaxo and Hansson, 1995; Bauer et al., 2005; Després et al., 2007). PBA components comprise the non- or semi-volatile chemical substances contained in PBA particles as well as the biogenic substances contained in other types of aerosol particles such as soil dust, sea spray, etc. (Wu et al., 2004; Fuzzi et al., 2006; Kellogg and Griffin, 2006). Matthias-Maser et al. (2000) have determined PBA mass concentrations of $\sim 6.5 \mu \mathrm{g} \mathrm{m}^{-3}$ for the aerosol particle size range $0.2-50 \mu \mathrm{m}$ in extratropical continental air, and Penner (1995) has estimated that plant fragments and microorganisms contribute $56 \mathrm{Tg} \mathrm{yr}^{-1}$ to the global emission rate of fine particulate matter $(\mathrm{D}<2.5 \mu \mathrm{m})$. Recently, Jaenicke (2005) has estimated that PBA emission from the biosphere may amount to $\sim 1000 \mathrm{Tg} \mathrm{yr}^{-1}$.

The occurrence and dispersion of microorganisms and spores in the air has been discussed and investigated very early in the history of aerosol science (Ehrenberg, 1830; Pasteur, 1860a, b). Since then, aircraft, balloon, and rocket measurements have shown that PBA particles are not only ubiquitous over land and oceans but also transported to high altitudes (up to $80 \mathrm{~km}$ ) and over long distances (Scheppergrell, 1924; Proctor, 1934; Meier, 1935; Rogers and Meier, 1936; Pady et al., 1950; Hirst et al., 1967b; Gregory, 1978; Imshenetsky et al., 1978; Watson and DeSousa, 1983; Griffin et al., 2001; McCarthy, 2001; Brown and Hovmoller, 2002; Yeo and Kim, 2002; Wainwright et al., 2003; Griffin, 2004; Prospero et al., 2005).

Pollen grains, fern spores, large fungal spores, and other large PBA particles typically belong to the coarse fraction of air particulate matter, with aerodynamic diameters up to one hundred micrometers. PBA particles and components are, however, also found in intermediate and fine fractions of air particulate matter, with aerodynamic diameters less than $10 \mu \mathrm{m}$ (PM10), $2.5 \mu \mathrm{m}$ (PM2.5), and $1 \mu \mathrm{m}$ (PM1), respectively: most fungal spores, small fragments and excretions of plants and animals, bacteria, viruses (Górny et al., 2002; Taylor et al., 2004; Pringle et al., 2005a); carbohydrates, proteins, waxes, ions, etc. are in this size range (Fish, 1972; Beauford et al., 1975; Miguel et al., 1999; Zhang and Anastasio, 2003; Franze et al., 2005; Pöschl, 2005). So far, however, the biological, chemical, and physical effects and mechanisms involved in the emission and dispersion of PBA particles and components have received little attention in biogeoscience and atmospheric research.

Here, we address the active (forcible) discharge of fungal spores, which is accompanied by the emission of aqueous droplets containing carbohydrates and inorganic ions. We summarize the information on the atmospheric abundance of wet and dry discharged fungal spores that is available from earlier scientific studies made at various locations around the world, and we present new measurement results and budget calculations for aerosol samples from tropical rainforests in Amazonia. Finally, we derive the first estimates for the global atmospheric emission rates of actively wet discharged basidiospores and of total fungal spores.

\section{Fungal species and discharge of fungal spores}

The number of different fungal species existing on Earth is assumed to be in the range of 1-1.5 million. Some 80000 to 120000 have been described to date (Hawksworth, 2003; Levetin, 2004; Webster and Weber, 2007), but only about 40000 are well-characterized (Rossman, 1994). Species in the biological kingdom of Fungi (Eumycota) can be grouped into the four divisions (phyla) Ascomycota (AM), Basidiomycota (BM), Chytridiomycota (CM), and Zygomycota (ZM) (Webster and Weber, 2007). Most of the fungal species found in the biosphere and atmosphere belong to AM and BM (Gregory and Sreeramulu, 1958; Chatterjee and Hargreave, 1974; Calderon et al., 1995; Decco et al., 1998; Newson et al., 2000; Kendrick, 2001; Troutt and Levetin, 2001; Helbling et al., 2002; Boreson et al., 2004; Hasnain et al., 2004; Fang et al., 2005; Hasnain et al., 2005; Zoppas et al., 2006; Butinar et al., 2007). CM and ZM are less frequently detected in the atmosphere.

Fungi are able to survive harsh environmental conditions, and viable forms have been found in deserts, hot biomass burning plumes, hailstones, subglacial ice of Arctic glaciers, glacial melt water, soils of snowcapped tundra, and deep sea sediments (Novozhilova and Popova, 1969; Mandrioli et al., 1973; Ma et al., 2000; Schadt et al., 2003; Boreson et al., 2004; Hasnain et al., 2004; Mims and Mims, 2004; Butinar et al., 2007; de Garcia et al., 2007).

Fungi can be pleomorphic, i.e. they can exist in two or more forms (morphs). Many well-known species of AM and BM occur in two morphs: a sexually reproducing form called the teleomorph (perfect state) and an asexually reproducing form termed the anamorph (imperfect state). The latter was formerly designated as Deuteromyces or Fungi Imperfecti. Molecular genetic methods, however, have enabled the unambiguous assignment of asexual anamorphs to the divisions specified above, and it has been suggested to discontinue using the terms Deuteromyces and Fungi Imperfecti (Kurtzman 
and Fell, 1998; Ribes et al., 2000; Hawksworth, 2004; Webster and Weber, 2007).

The reproduction of fungi proceeds via budding (asexual) or sporulation (sexual or asexual), and fungal spores or conidia (asexual spores generated by mitosis) are dispersed via a variety of mechanisms (Buller, 1909-1950; Ingold, 1971; Lacey, 1996; Ingold, 1999). In this study, the term "spores" refers to both sexual spores and asexual spores (conidia), unless mentioned otherwise.

In the following, we concentrate on those species of Ascomycota and Basidiomycota that actively discharge their spores with liquid jets or droplets into the air. We designate these species as "actively wet spore discharging Ascomycota" (AAM) and "actively wet spore discharging Basidiomycota" (ABM), which account for a major fraction of the known AM and BM, respectively (Ingold, 2001a, b; Pringle et al., 2005b)

\subsection{Actively wet spore discharging Ascomycota (AAM)}

AAM exist as saprophytes on dead biomass as well as endophytes or parasites in/on living organisms. In combination with algae, they form lichens which live as epiphytes on plants or on other surfaces, such as rocks, house walls etc. They are found in most regions and climate zones of the world.

The spores of AAM, which we designate as actively wet discharged ascospores (AAS), are typically $2-20 \mu \mathrm{m}$ in aerodynamic diameter (Buller, 1909; Ingold, 2001b) and mature within apothecia. These are composed of small sacks (asci) filled with epiplasmic fluids, and they contain a mix of organic and inorganic solutes. For example, a mature ascus of Giberella zeae holds a liquid volume of $\sim 7 \times 10^{-15} \mathrm{~m}^{3}$ with mannitol $\left(4.7 \pm 2.2 \times 10^{-12} \mathrm{~g}\right)$, potassium $\left(4.6 \times 10^{-11} \mathrm{~g}\right)$, and chloride $\left(1.4 \times 10^{-11} \mathrm{~g}\right)$ as the main solutes (Trail et al., 2005). Glycerol and proline ( $37 \pm 6$ and $8 \pm 3 \mathrm{mmol} / \mathrm{L}$, respectively) were found in the ascus sap of Ascobolus immersus (Fischer et al., 2004). To our knowledge, other data on the chemical composition of ascus sap are not available.

The asci are pressurized osmotically and, upon discharge, spores and droplets of epiplasmic fluid are vigorously ejected through a narrow aperture at the tip of the bursting asci (Buller, 1909; Ingold, 2001a; Trail et al., 2002). The size and number of the ejected aqueous droplets are similar to the size and number of spores (twice as many droplets in the case of Giberella zeae, Trail et al., 2002). The discharge distance ranges from about one to several hundred millimeters in still air (Buller, 1909; Ingold, 1971; Meredith, 1973). Ingold (1971) pointed out that "in the great majority of Ascomycetes, the largest group of the Fungi, the ascus is a turgid cell that finally bursts in a regular manner violently liberating its contained ascospores".

Raynal (1990) found that individual apothecia of Sclerotinia trifoliorum ejected up to $4.7 \times 10^{6}$ AAS over their entire life cycle. Ingold (1971) reported that individual apothecia of
Cookeina sulcipes can discharge $3-24 \times 10^{6}$ AAS, and Hong and Michailides (1998) determined a release of $2-37 \times 10^{6}$ AAS per AAM fruiting body of Monilinia fructicola. Venette (1998) reported that a single apothecium of Sclerotinia sclerotiorum can discharge $2-30 \times 10^{6}$ AAS over a period of several days and estimated a potential spore load of $0.2-3 \times 10^{12}$ AAS for this fungus per ha of grain field (Table A1). For Venturia inaequalis, AAS emission fluxes of $10^{2}-10^{4} \mathrm{~m}^{-2} \mathrm{~s}^{-1}$ have been reported from a grass field in Connecticut, USA (Aylor and Flesch, 2001; de Jong et al., 2002).

\subsection{Actively wet spore discharging Basidiomycota (ABM)}

ABM comprise a large number of mushrooms, bracket and jelly fungi, smut and rust fungi, as well as basidiomycetous yeasts ( $\sim 30000$ known species, Pringle et al., 2005b). The actively wet discharged basidiospores (ABS) emitted by these fungi grow on little pedestals called basidia (Buller, 1909; Gregory, 1973). In the literature, a variety of different terms have been used for ABS: ballistospores, ballistosporic basidiospores, ballistoconidia, ballistosporic conidia, secondary ballistospores, secondary spores, or secondary conidia (Buller, 1909-1950; Buller, 1934; Taylor, 1970; Ingold, 1971; Mims and Richardson, 1990; Boekhout, 1991; Hanlin, 1994; Bauer and Oberwinkler, 1997; Kurtzman and Fell, 1998; Piepenbring et al., 1998; Nakase, 2000; Carlile et al., 2001; Ingold, 2001b; Barnett and Robinow, 2002; Davoli and Weber, 2002; Scorzetti et al., 2002; Pringle et al., 2005b).

The aerodynamic diameters of ABS typically range from 2 to $10 \mu \mathrm{m}$ (Boekhout, 1991; Lin and $\mathrm{Li}, 1996$; Golubev, 1999; Takashima and Nakase, 2001; Ingold, 2001b; Bai et al., 2002; Burge, 2002; Zhao et al., 2003; Wu et al., 2004). Their active discharge was already noted in the $19^{\text {th }}$ century, but only recently was the discharge mechanism elucidated and termed "surface tension catapult" (Turner and Webster, 1991; Pringle et al., 2005b). It involves an aqueous droplet near the basal end of the spore called the "Buller's drop" (Buller, 1915, 1922; Buller and Vanterpool, 1925), and a thin liquid film on the distal end of the spore. At high relative humidity they both grow by hygroscopic uptake of water vapor. Upon reaching a size comparable to the spore, Buller's drop and the liquid film merge, and the generated momentum propels the spore, enveloped by the liquid, away from the basidium - typically over distances of $0.1-1.5 \mathrm{~mm}$ (Webster et al., 1989; Turner and Webster, 1995; Ingold, 1997, 1999; Pringle et al., 2005b) (http://www.anbg.gov.au/fungi/ spore-discharge-mushrooms.html).

The solutes found in Buller's drops of the basidiomycetous yeast Itersonilia perplexans are mainly hexoses and mannitol (3.8 and 5.3 pg per spore, respectively) plus smaller (but not quantified) quantities of inorganic ions like phosphate, sodium and potassium (Webster et al., 1995). To our knowledge, other data on the chemical composition of the Buller's drop are not available. 
Buller (1909) reported that a single fruiting body of a mushroom (basidiocarp) can discharge as many as $4-10 \times 10^{7}$ ABS per hour (Psalliota campestris and Coprinus comatus), $6.8 \times 10^{8}$ ABS per week (Daedalea confragosa), or 1$10 \times 10^{10}$ ABS per year (Polyporus squamosus), respectively (Table A1). Meredith (1973) reported discharge rates of $3 \times 10^{10}$ ABS per day over periods up to 6 months for artist's conk (Ganoderma applanatum).

Several other fungal species also actively discharge their propagating units with liquid jets or droplets, but not via the mechanisms specified above, e.g., Basidiobolus, Conidiobolus, Entomophtora, Pilobolus (ZM) and Sphaerobolus stellatus (BM) (Buller, 1909; Couch, 1939; Page, 1964; Ingold, 1999; Ribes et al., 2000). The chemical composition of these liquids is, however, not known, and the occurrence of spores from these species in air samples has been reported much less frequently. Therefore, these species are not considered any further in this study. In the budget calculations presented below, we also do not consider the potential release of additional chemical compounds from inside the fungal spores, as their walls are not easily ruptured under the conditions usually applied for the extraction of aerosol filter samples for chemical analysis (Weijman, 1979; Suzuki and Nakase, 1988; Davoli and Weber, 2002; Graham et al., 2002; Solomon et al., 2006). Nevertheless, these aspects may merit further investigation in future studies aimed at fully unraveling the primary biogenic components of air particulate matter.

\subsection{Dry spore discharging fungi}

Several fungi do not actively discharge spores with liquid jets or droplets into the air. Their spores are dislodged by air currents or detached by other external forces. Some species are thought to actively support the detachment of spores (conidia) by a process called hygroscopic twisting movement (HTM) which occurs upon drying (Meredith, 1963). In any case, the spores of these fungi are discharged without accompanying liquids and can be summarized under the term "dry discharged spora" (DDS), which is comparable to the terms "dry air spora" or "fine weather spores" used by Gregory (1971) and Levetin (2004), respectively. Prominent representatives of dry spore discharging fungi are species of the genera Aspergillus, Aureobasidium, Penicillium (AM) and Cladosporium (BM).

\section{Abundance of fungal spores and related chemical components in air particulate matter}

\subsection{Wet and dry discharged spores}

The abundance of fungal spores in the air is highly variable, and is dependent upon location, season, time of day, and weather. Air masses with low concentrations of spores can be intercepted by plumes with very high concentrations
(Hirst et al., 1967b; Chatterjee and Hargreave, 1974; Burch and Levetin, 2002).

Table A2 summarizes ambient concentrations of AAS (a) and $\mathrm{ABS}$ (b) reported in earlier studies, and the results of our microscopic investigations of aerosol filter samples collected in the tropical rainforest of Amazonia. Overall, the concentrations range from zero to $\sim 10^{4} \mathrm{~m}^{-3}$, with exceptional maximum values up to $\sim 10^{6} \mathrm{~m}^{-3}$ (Gregory and Sreeramulu, 1958; Frankland and Gregory, 1973). Most of the concentrations reported for AAS and ABS, including the few data available from tropical regions (Brazil, Mexico, Taiwan), range between $10^{3} \mathrm{~m}^{-3}$ and $10^{4} \mathrm{~m}^{-3}$.

Precipitation appears to be required for the release of spores from many AAM, and AAS concentrations have been found to increase during and after rainstorms. The release and resultant airborne concentrations of ABS, on the other hand, appear to be more directly correlated with relative humidity rather than precipitation (Gregory and Hirst, 1957; Gregory and Sreeramulu, 1958; Hirst et al., 1967a; Ingold, 1971; Meredith, 1973; Chatterjee and Hargreave, 1974; Stephen et al., 1990; Gottwald et al., 1997; Burch and Levetin, 2002; Zoppas et al., 2006).

DDS are mostly emitted when dry, warm, and windy conditions prevail; the wind speed required for the discharge of DDS is typically on the order of $\sim 1 \mathrm{~m} \mathrm{~s}^{-1}$ (Meredith, 1963; Meredith, 1973; Shaner, 1981; Lacey, 1996; Timmer et al., 1998; Byrne et al., 2000; Aylor et al., 2001; Carlile et al., 2001; Burch and Levetin, 2002; Górny et al., 2002; Glovsky et al., 2003). The atmospheric concentrations reported for DDS in the size range of $2-10 \mu \mathrm{m}$ are mostly on the order of $10^{3}-10^{4} \mathrm{~m}^{-3}$, i.e. comparable to the average concentrations of ABS and AAS (Gregory and Hirst, 1957; Gregory and Sreeramulu, 1958; Adams et al., 1968; Chatterjee and Hargreave, 1974; Kramer and Eversmeyer, 1984; Li and Kendrick, 1995; Newson et al., 2000; Troutt and Levetin, 2001; Levetin, 2004; Wu et al., 2004; Fang et al., 2005; Ho et al., 2005; Zoppas et al., 2006).

The above data for AAS, ABS, and DDS are consistent with recent studies investigating total concentrations of fungal spores in alpine air $\left(\sim 10^{3} \mathrm{~m}^{-3}\right.$; Mt. Rax, Austria) and urban air $\left(8-26 \times 10^{3} \mathrm{~m}^{-3}\right.$; Vienna, Austria), corresponding to $2-6 \%$ of the organic carbon fraction and up to $1.3 \%$ of the total mass of air particulate matter (Bauer et al., 2002; Bauer et al., 2005). In rural air over an agricultural region, Burch and Levetin (2002) recorded concentrations of total fungal spores in the range of $2-17 \times 10^{4} \mathrm{~m}^{-3}$ (Bixby/Tulsa, USA). They also reported that dry discharged fungal spores (DDS) were enhanced during warm, dry weather conditions, whereas actively wet discharged AAS and ABS concentrations tend to be enhanced during humid conditions, such as those at night and in the early morning. Most studies of total fungal spores in continental air around the world have reported concentrations on the order of $10^{4} \mathrm{~m}^{-3}$ (Newson et al., 2000; Troutt and Levetin, 2001; Wu et al., 2004; Ho et al., 2005; Zoppas et al., 2006). 


\subsection{Tropical rainforest aerosol samples}

The air samples used in our own experimental investigations were collected at the beginning of the dry season at Balbina, Amazonia, Brazil, ( $1^{\circ} 55^{\prime} \mathrm{S}, 59^{\circ} 24^{\prime} \mathrm{W}, 174 \mathrm{~m}$ above sea level) on a pasture site adjacent to pristine tropical rainforest. Samples for microscopic examination were taken with a rotating impactor and with an isokinetic 2-stage jet impactor positioned $2 \mathrm{~m}$ above the ground. Air samples for the determination of inorganic ions in fine particulate matter $(\leq 2 \mu \mathrm{m})$ and coarse particles $(2-10 \mu \mathrm{m})$ were taken with two-stage stacked filter units (SFU). Sugars and sugar alcohols were determined in aerosol particle samples collected with a dichotomous high-volume (HiVol) sampler: fine $(\leq 2.5 \mu \mathrm{m})$ and coarse $(\geq 2.5 \mu \mathrm{m})$. Both the SFU and the HiVol samplers were positioned $4 \mathrm{~m}$ above the ground (Graham et al., 2003a; Graham et al., 2003b; Moura et al., 2004).

AAS and ABS were determined by detailed microscopic investigation of two exemplary samples collected with the jet impactor on 22 July 2001 (local time of sampling: 09:1009:48 and 23:55-01:05). The samples were mounted and directly observed with a Nikon 80i light microscope at up to $1500 \mathrm{x}$ magnification. Fungal spore types were identified based on their morphology in 200 fields of view for each sample. Counts were expressed per cubic meter of air sampled.

Fungal spores $(2-20 \mu \mathrm{m})$ were generally most abundant in night-time samples when the relative humidity was close to $100 \%$, whereas the concentration of larger fern spores and pollen was typically higher in day-time samples (Graham et al., 2003a). The night-time concentrations were $\sim 7400 \mathrm{~m}^{-3}$ for AAS and $\sim 12800 \mathrm{~m}^{-3}$ for ABS $\left(\sim 3600 \mathrm{~m}^{-3}\right.$ from rust fungi and $\sim 9150 \mathrm{~m}^{-3}$ from smut fungi); the day-time concentrations were $\sim 3000 \mathrm{~m}^{-3}$ for AAS and $\sim 1800 \mathrm{~m}^{-3}$ for ABS (almost exclusively from rust fungi). The results are consistent with the general trends and concentrations of AAS, ABS, and total fungal spores observed in earlier investigations (as outlined above), in a recent study of colonyforming spores sampled from a tropical rainforest in Australia (Gilbert and Reynolds, 2005), and in a study conducted in a tropical pluvial location in the south of Brazil (Zoppas et al., 2006).

\subsection{Carbohydrates: mannitol, glucose, and fructose}

Table A3 gives an overview of the concentrations reported for the sugar alcohol mannitol $\left(\mathrm{C}_{6} \mathrm{H}_{14} \mathrm{O}_{6}\right)$ in atmospheric aerosols. At extratropical locations, the average concentrations of mannitol were $1-11 \mathrm{ng} \mathrm{m}^{-3}$ for particles $\leq 2.5 \mu \mathrm{m}$ and $4-97 \mathrm{ng} \mathrm{m}^{-3}$ for particles $\geq 2.5 \mu \mathrm{m}$. In aerosol samples from Amazonia and Rondônia (Brazil), average mannitol concentrations were 2-3 times higher than at extratropical locations: $8-26 \mathrm{ng} \mathrm{m}^{-3}$ for particles $\leq 2.5 \mu \mathrm{m}$, and $29-$ $112 \mathrm{ng} \mathrm{m}^{-3}$ for particles $\geq 2.5 \mu \mathrm{m}$. Investigations with separate day-time and night-time samples of particles $\geq 2.5 \mu \mathrm{m}$ showed that the night-time concentrations of mannitol were higher by factors of 2-3 (Graham et al., 2002; Graham et al., 2003b; Claeys et al., 2004). Recent investigations with an 11-stage MOUDI aerosol impactor showed that the mass size distribution of mannitol in tropical rainforest aerosols (Rondônia, Brazil) exhibited a maximum at particle diameters around $5 \mu \mathrm{m}$. The maximum was particularly pronounced (up to three orders of magnitude higher than the lowest values of the size distribution function) during nights of the dry season and throughout the transition and wet seasons (Decesari et al., 2006; Fuzzi et al., 2007). In the wet season the total aerosol mass size distribution function was also dominated by a pronounced maximum at particle diameters around $5 \mu \mathrm{m}$ (Fuzzi et al., 2007).

Table A4 gives an overview of the atmospheric concentrations observed for the hexose sugars, glucose and fructose $\left(\mathrm{C}_{6} \mathrm{H}_{12} \mathrm{O}_{6}\right)$. In contrast to mannitol, the average glucose and fructose concentrations determined in samples of air particulate matter from Amazonia and Rondônia (Brazil), were not higher than at extratropical locations: 1$49 \mathrm{ng} \mathrm{m}^{-3}(\leq 2.5 \mu \mathrm{m})$ and $3-146 \mathrm{ng} \mathrm{m}^{-3}(\geq 2.5 \mu \mathrm{m})$ at tropical locations; $10-15 \mathrm{ng} \mathrm{m}^{-3}(\leq 2.5 \mu \mathrm{m})$ and $1-270 \mathrm{ng} \mathrm{m}^{-3}$ $(\geq 2.5 \mu \mathrm{m})$ at extratropical locations. Moreover, studies with separate day-time and night-time sampling at tropical sites showed a diurnal cycle opposite to that of mannitol: glucose and fructose concentrations were strongly enhanced during day-time (up to 50 times higher than at night) (Graham et al., 2003b).

\section{Contribution of AAM and ABM emissions to the con- centration and composition of Amazonian rainforest aerosols}

Tables A5 and A6 give an overview of potassium and chloride ion concentrations in atmospheric aerosols observed during the wet season at various locations in Amazonia. The concentrations of potassium were typically in the range of $18-220 \mathrm{ng} \mathrm{m}^{-3}$ for particles $\leq 2 \mu \mathrm{m}$ and $14-270 \mathrm{ng} \mathrm{m}^{-3}$ for particles in the size range of $1-15 \mu \mathrm{m}$, respectively, and night-time concentrations generally exceeded day-time concentrations (Graham et al., 2003a; Fuzzi et al., 2007). The chloride concentrations were in the range of $5-65 \mathrm{ng} \mathrm{m}^{-3}$ for particles $\leq 2 \mu \mathrm{m}$ and $8-155 \mathrm{ng} \mathrm{m}^{-3}$ for particles with diameters of $2-15 \mu \mathrm{m}$, respectively. Table A7 lists total particle mass concentrations recorded during the wet season at various locations in Amazonia. Long-term average values for the particle size range of $2-10 \mu \mathrm{m}$ were typically $5-16 \mu \mathrm{g} \mathrm{m}^{-3}$ (Artaxo et al., 1990; Formenti et al., 2001; Guyon et al., 2003). Studies with separate day- and night-time sampling showed that particle mass concentrations were 2-4 times higher at night (Graham et al., 2003a; Fuzzi et al., 2007).

To calculate an estimate of the relative contribution of fungal emissions to the chemical composition of coarse air particulate matter (particle diameters $1-2 \mu \mathrm{m}$ to $10-15 \mu \mathrm{m}$ ) in 
Table 1. Liquid concentrations of species ejected with AAS (Trail et al., 2005) and ABS (Webster et al., 1995) taken as representative average values for budget calculations.

\begin{tabular}{lll}
\hline Species & $\begin{array}{l}\text { Buller's Drop } \\
\text { (pg/Spore) }\end{array}$ & $\begin{array}{l}\text { Ascus Sap } \\
\text { (pg/Ascus) }\end{array}$ \\
\hline Mannitol & 5.3 & 4.7 \\
Hexoses & 3.8 & nd \\
Potassium & nd & 45.9 \\
Chloride & nd & 14.3 \\
Solutes & 9.1 & 64.9 \\
\hline
\end{tabular}

nd: not determined

the tropical rainforest of Amazonia during the wet season, we used the parameters listed in Table 1, which have been derived from the literature (Webster et al., 1995; Trail et al., 2005). For the average mass of AAS we assumed a value of $200 \mathrm{pg}$ for AAS, corresponding to a volume equivalent diameter of $\sim 7 \mu \mathrm{m}$ and density of $\sim 1 \mathrm{~g} \mathrm{~cm}^{-3}$ (Trail et al., 2005). For ABS we assumed an average mass of $65 \mathrm{pg}$, corresponding to a volume equivalent diameter of $\sim 5 \mu \mathrm{m}$ and density of $\sim 1 \mathrm{~g} \mathrm{~cm}^{-3}$ (Buller, 1909; Ingold, 1971; Lin and Li, 1996; Ingold, 2001b; Wu et al., 2004) and consistent with the maximum of mannitol and PM size distributions observed in tropical rainforest aerosols during the wet season (Fuzzi et al., 2007). This is a lower estimate compared to the $840 \mathrm{pg}$ per ABS of I. perplexans reported by Turner and Webster (1991), which would correspond to a volume equivalent diameter of $\sim 12 \mu \mathrm{m}$ at $\sim 1 \mathrm{~g} \mathrm{~cm}^{-3}$. For AAS, the number of spores per ascus can vary over a range of about $1-100$. Nevertheless, an average number of 8 spores per ascus has been determined for the majority of AAM and was used in our calculations (Ingold, 1971).

By multiplication of the parameters outlined above with the measured number concentrations of AAS and ABS, we obtained the mass concentration estimates listed in Table 2 and illustrated in Figs. 1-4.

For mannitol (Fig. 1), the estimated fungal emissions are dominated by ABS and account for $100 \%$ of the night-time, $35 \%$ of the day-time, and $80 \%$ of the average concentrations, which have been determined in two independent measurements at the same location and period of time (Balbina: 19-28 July 2001, (Graham et al., 2003b); 25-28 July 2001, (Claeys et al., 2004); particle diameters $\geq 2.5 \mu \mathrm{m}$ ).

For the hexoses (Fig. 2), the fungal emission estimate (related to ABS only) exceeds the measured night-time concentrations of glucose and fructose by a factor of 10. During day-time the estimated fungal emissions would account for only $\sim 10 \%$, and averaged over $24 \mathrm{~h}$ they would account for $\sim 60 \%$ of the observed concentrations.

For potassium (Fig. 3), the estimated fungal emissions (related to AAS only) account for $\sim 60 \%$ of the average concentration measured at the same location and period of time

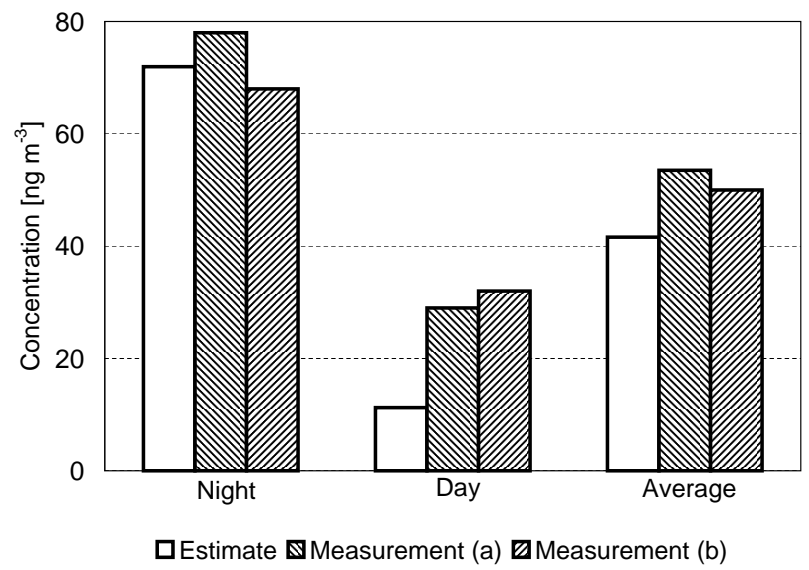

Fig. 1. Mannitol concentrations in ambient air in Amazonia (Balbina, Brazil; wet season): estimate from spore counts (this study) compared to measurements of (a) Graham et al. (2003b; plotted: mean values of 6 samples; night-time standard deviation (SD): $\pm 15 \mathrm{n} \mathrm{m}^{-3}$; day-time SD: $\pm 8 \mathrm{ng} \mathrm{m}^{-3}$; concentration range: 24 $102 \mathrm{ng} \mathrm{m}^{-3}$ ) and (b) Claeys et al. (2004; plotted: mean values).

(Balbina: 16-28 July 2001, (Graham et al., 2003a); particle diameters 2-10 $\mu \mathrm{m}$; separate day- and night-time values not available). Compared to measurement data from a different place and time during the wet season in Amazonia (FNS: Fazenda Nossa Senhora Aparecida, near Ouro Preto do Oeste, Rondônia) (Fuzzi et al., 2007), the day- and night-time estimates would account for practically all of the potassium in the investigated aerosol particle size range (1$10 \mu \mathrm{m})$ and are consistent with the observed diurnal cycle.

For chloride (Tables A6 and 2), the estimated fungal emissions (related to AAS only) account for $\sim 15 \%$ of the average concentration measured at the same location and period of time (Balbina: 16-28 July 2001, (Graham et al., 2003a; particle diameters $2-10 \mu \mathrm{m}$; separate day- and night-time values not available).

For total mass of particulate matter (Fig. 4), the estimated emissions by actively wet spore discharging fungi are dominated by the spores rather than the solutes (solute mass fraction only 5-10\%) and account for $\sim 45 \%$ of the night-time, $\sim 25 \%$ of the day-time, and $\sim 35 \%$ of the average concentrations measured at the same location and period of time (Balbina: 22-25 July 2001, Graham et al., 2003a); particle diameters 2-10 $\mu \mathrm{m})$. Compared to measurement data from FNS (Fuzzi et al., 2007), the estimated proportion of fungal emissions in particles sized $1-10 \mu \mathrm{m}$ in diameter would be slightly lower at night, higher during the day, and similar on average. 
Table 2. Measured and calculated concentrations of spores and related chemical components in air particulate matter from Balbina: measured number concentrations of ABS and AAS; calculated mass concentrations of solutes and spores (calculations as detailed in Sect. 4).

\begin{tabular}{llllllll}
\hline & \multicolumn{2}{c}{ ABS } & \multicolumn{2}{c}{ AAS } & \multicolumn{3}{c}{ AAS + ABS } \\
& Day & Night & Day & Night & Day & Night & Average \\
\hline Spores $\left(\mathrm{m}^{-3}\right)$ & 1800 & 12772 & 2964 & 7416 & 4764 & 20188 & 12476 \\
Mannitol $\left(\mathrm{ng} \mathrm{m}^{-3}\right)$ & 9.5 & 67.7 & 1.7 & 4.3 & 11.2 & 72 & 41.6 \\
Hexoses $\left(\mathrm{ng} \mathrm{m}^{-3}\right)$ & 6.8 & 48.5 & nd & nd & 6.8 & 48.5 & 27.7 \\
Potassium $\left(\mathrm{ng} \mathrm{m}^{-3}\right)$ & nd & nd & 17.3 & 43.3 & 17.3 & 43.4 & 29.8 \\
Chloride $\left(\mathrm{ng} \mathrm{m}^{-3}\right)$ & nd & nd & 5.3 & 13.3 & 5.3 & 13.3 & 9.3 \\
Solute Mass $\left(\mathrm{ng} \mathrm{m}^{-3}\right)$ & 16.4 & 116 & 24.3 & 60.9 & 40.7 & 177 & 108 \\
Spore Mass $\left(\mathrm{ng} \mathrm{m}^{-3}\right)$ & 118 & 835 & 592 & 1483 & 710 & 2318 & 1514 \\
\hline
\end{tabular}

nd: not determined

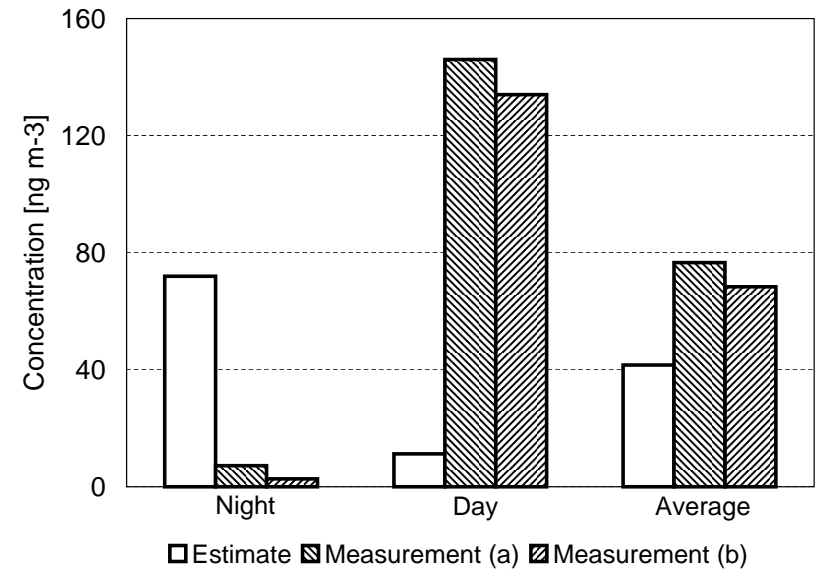

Fig. 2. Hexose (glucose and fructose) concentrations in ambient air in Amazonia (Balbina, Brazil; wet season): estimate from spore counts (this study) compared to measurements of (a) Graham et al. (2003b; plotted: mean values of 6 samples; night-time SD: $\pm 5 \mathrm{ng} \mathrm{m}^{-3}$; day-time SD: $\pm 45 \mathrm{ng} \mathrm{m}^{-3}$; concentration range: 4 $200 \mathrm{ng} \mathrm{m}^{-3}$ ) and (b) Claeys et al. (2004; plotted: mean values).

\section{Global emission estimates for ABS and total fungal spores}

As outlined above (Sect. 3.1, Table A2), the knowledge about the abundance and activity of fungi in the global biosphere is very limited. To our knowledge, regional or global estimates for the emission rates and fluxes of wet and dry discharged fungal spores are not available in the literature.

Here, we calculate a first estimate for the global average emission rate of ABS over land surfaces based on the following first-order approximations and assumptions:

1. The abundance of mannitol in the atmosphere is assumed to be dominated by emissions from ABM, which is supported by the literature data and results outlined above (Table A2: similar abundance of AAS and ABS; Table 1: higher amount of mannitol emitted with one

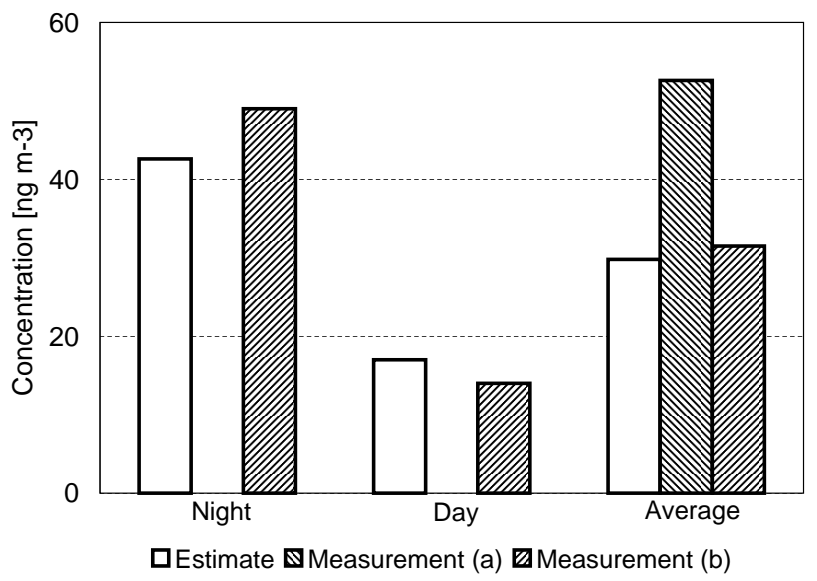

Fig. 3. Potassium concentrations in ambient air in Amazonia (wet season): estimate from spore counts at Balbina (this study) compared to measurements at (a) Balbina (Graham et al., 2003a; plotted: mean value of 8 samples; SD of diurnal average: $\pm 29 \mathrm{ng} \mathrm{m}^{-3}$ ) and (b) FNS, Rondônia (Fuzzi et al., 2007; plotted: mean values; night-time $\mathrm{SD}: \pm 36 \mathrm{ng} \mathrm{m}^{-3}$; day-time SD: $\pm 10 \mathrm{ng} \mathrm{m}^{-3}$ ).

ABS per Buller's drop compared to eight AAS per ascus; Table 2 and Fig. 1: consistency of exemplary calculations).

2. The literature-derived value of $5 \mathrm{pg}$ mannitol emitted per ABS (Table 1) is assumed to be representative for ABM, which is supported by the results outlined above (Table 2 and Fig. 1: consistency of exemplary calculations).

3. The average value of mannitol concentrations reported for PM with particle diameters up to $10 \mu \mathrm{m}$ or more at extratropical measurement locations $\left(25 \mathrm{ng} \mathrm{m}^{-3}\right.$, Table A3, lines 11-17) is assumed to be representative for a well-mixed continental boundary layer (CBL) with an average height of $\sim 1 \mathrm{~km}$ (Seinfeld and Pandis, 1998; Strawbridge and Snyder, 2004; Elbert, 2006). 


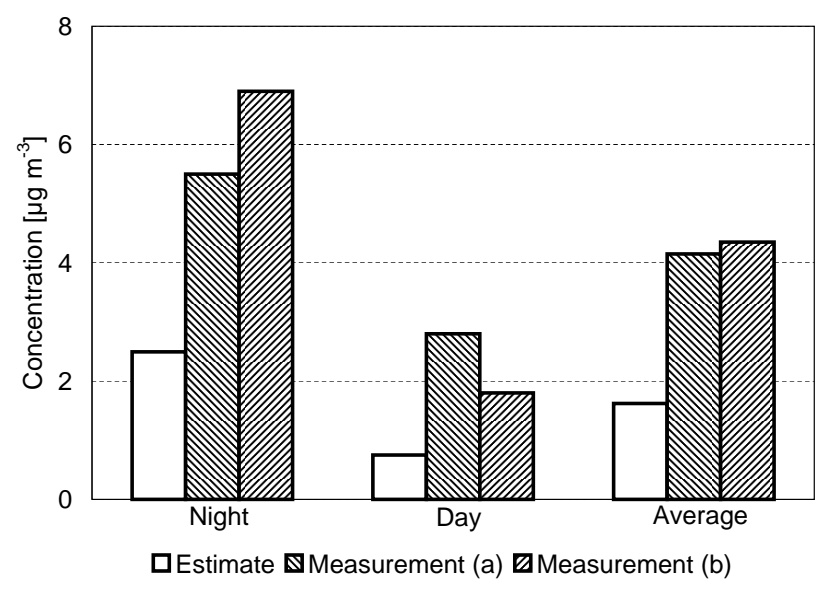

Fig. 4. Aerosol mass concentration in ambient air in Amazonia (wet season): estimate from spore counts at Balbina (this study) compared to measurements at (a) Balbina (Graham et al., 2003a; plotted: mean values) and (b) FNS, Rondônia (Fuzzi et al., 2007; plotted: mean values; night-time SD: $\pm 5.2 \mu \mathrm{g} \mathrm{m}^{-3}$; day-time SD: $\pm 1.3 \mu \mathrm{g} \mathrm{m}^{-3}$ ).

The following evidence supports these assumptions as conservative: significantly higher mannitol concentrations reported from tropical regions (Table A3); significantly higher and well-mixed day-time CBLs in tropical regions (Graham et al., 2003b); observation of elevated spore concentrations in the upper part of the CBL (Meier and Artschwager, 1938; Hirst et al., 1967b; Linskens and Jorde, 1986).

4. The average size and residence times of $\mathrm{ABS}$ in the CBL are assumed to be on the order of $5 \mu \mathrm{m}$ and 1 day, respectively, which is supported by the literature data and results outlined above (Table 2 and Fig. 4: consistency of exemplary calculations) and by the basic concepts of atmospheric aerosol cycling (rapid sedimentation and wet deposition of coarse particles).

Dividing the average mannitol concentration of $25 \mathrm{ng} \mathrm{m}^{-3}$ by $5 \mathrm{pg}$ (amount of mannitol emitted per ABS) we obtain a value of $5 \times 10^{3} \mathrm{~m}^{-3}$ as a first-order estimate for the global average number concentration of ABS in the continental boundary layer, which is consistent with the observations summarized in Table A2b and discussed in Sect. 3.1. Multiplication with an average spore mass of $65 \mathrm{pg}$ yields a value of an average contribution of $0.3 \mu \mathrm{g} \mathrm{m}^{-3}$ to the concentration of air particulate matter, which is also consistent with the observations reported in Sect. 3.1. As demonstrated above, the total mass concentration of actively wet discharged spores (ABS and AAS) and related substances observed in tropical rainforest regions during the wet season are significantly higher, supporting the above values as conservative estimates.

Multiplication of the average number concentration with an average CBL height of $\sim 1000 \mathrm{~m}$ and division by an average residence time on the order of $\sim 1$ day yields an es- timate of $\sim 60 \mathrm{~m}^{-2} \mathrm{~s}^{-1}$ for the globally averaged land surface emission flux of ABS. By multiplication with an average spore mass of $\sim 65 \mathrm{pg}$, the global land surface area of $1.5 \times 10^{14} \mathrm{~m}^{2}$ and the duration of one year we obtain an estimate of $\sim 17 \mathrm{Tg} \mathrm{yr}^{-1}$ for the global emission rate of ABS. Based on the similar magnitudes of the atmospheric abundances of ABS, AAS, and DDS (Sect. 3.1), we estimate that the global land surface emission flux and emission rate of total fungal spores are on the order of $\sim 200 \mathrm{~m}^{-2} \mathrm{~s}^{-1}$ and $\sim 50 \mathrm{Tg} \mathrm{yr}^{-1}$, respectively.

This is only a small fraction of the total PBA emission rate of $1000 \mathrm{Tg}$ yr-1 estimated by Jaenicke (2005), but it is of similar magnitude as current estimates of the rates of emission and formation of other types of continental air particulate matter: $\sim 47 \mathrm{Tg} \mathrm{yr}^{-1}$ for anthropogenic primary organic aerosols (POA) made up of $35 \mathrm{Tg} \mathrm{yr}^{-1}$ from vegetation fires, $9 \mathrm{Tg} \mathrm{yr}^{-1}$ from biofuel combustion, $3 \mathrm{Tg} \mathrm{yr}^{-1}$ from fossil fuel combustion; $3-25 \mathrm{Tg} \mathrm{yr}^{-1}$ for anthropogenic secondary organic aerosols (SOA) (Volkamer et al., 2006); and $12-70 \mathrm{Tg} \mathrm{yr}^{-1}$ for biogenic SOA (mostly from terpene oxidation) (Kanakidou et al., 2005).

Gregory and Sreeramulu (1958) have reported high emissions of fungal spores from a marine estuary. On a global scale, however, the oceans appear to be a negligibly small source of fungal spores. A rough estimate of potential emissions of fungal spores/cells can be obtained by scaling the global emission rate of sea salt aerosol $\left(\sim 10^{3}-10^{4} \mathrm{Tg} \mathrm{yr}^{-1}\right.$; (Seinfeld and Pandis, 1998; Raes et al., 2000; Stier et al., 2005; Textor et al., 2006) with reported proportions of fungal cells and sea salt in surface ocean water $\left(10^{2}-10^{3}\right.$ cells per liter corresponding to $10^{-8}-10^{-7} \mathrm{~g} / \mathrm{kg}$; sea salt: $\sim 35 \mathrm{~g} / \mathrm{kg}$; (Novozhilova and Popova, 1969; Yamasato et al., 1974; Gadanho et al., 2003)). The resulting value of $\sim 10 \mathrm{t} \mathrm{yr}^{-1}$ is six orders of magnitude smaller than the land surface emission estimate, and even a significant enrichment during sea spray formation is unlikely to result in a large global marine source of fungal material.

\section{Conclusions and outlook}

In this study we have shown that actively wet spore discharging Ascomycota (AAM) and Basidiomycota (ABM) are a major source of primary biogenic aerosol (PBA). These primary biogenic components of coarse air particulate matter (characteristic size range 1-10 $\mu \mathrm{m}$ ) may influence the formation of clouds and precipitation as cloud condensation and ice nuclei, and they affect the spread and reproduction of organisms in the biosphere. The effects of fungal emissions might be particularly important in tropical regions where both physicochemical processes in the atmosphere and biological activity at the Earth's surface are particularly intense. In pristine tropical rainforest air, fungal spores indeed account for a major fraction of coarse particulate matter (up to $\sim 45 \%$ ). 
Using the chemical tracer mannitol and measurement data from around the world, we have derived first estimates for the global average emission rates of fungal spores. The estimated emission rate of total fungal spores $\left(\sim 50 \mathrm{Tg} \mathrm{yr}^{-1}\right)$ is of similar magnitude as current estimates of the rates of emission and formation of other types of continental air particulate matter (primary and secondary organic aerosols).

The use of fungi as biocontrol agents might lead to a manmade increase of airborne spores (Burge, 2002; de Jong et al., 2002). Moreover, global warming and increasing $\mathrm{CO}_{2}$ concentrations may enhance the spread of fungi and emission of fungal spores (Klironomos et al., 1997; Høye et al., 2007; Raupach et al., 2007). An increase of fungal spores acting as cloud condensation and ice nuclei may influence the hydrological cycle and provide either positive or negative feedbacks to climate change.

For further insight and understanding of seasonal and regional variations, vertical profiles, and long-range transport of fungal spores and related aerosol components, additional ground-based and airborne measurements of these species will be required. Moreover, a reliable assessment of the overall role of bioaerosols in the climate system and of the relative importance of fungal emissions will require similar investigations for other abundant primary biogenic aerosol particles such as pollen and bacteria. To capture the high biological diversity and the high temporal and spatial variability of airborne fungal spores and other PBA particles, advanced molecular biological analyses and online measurement techniques will be needed (Pöschl, 2005; Després et al., 2007; Treutlein and Pöschl, 2007).

\section{Appendix A}

Table A1. Active wet discharge of spores by Ascomycota (AAM) and Basidiomycota (ABM).

\begin{tabular}{llll}
\hline Amount & Unit & Species & References \\
\hline & & Ascomycota & \\
$2-37 \times 10^{6}$ & per apothecium & $\begin{array}{l}\text { Monilinia fructicola } \\
\text { Cookeina sulcipes }\end{array}$ & (Hong and Michailides, 1998) \\
$3-24 \times 10^{6}$ & per apothecium & (Ingold, 1971) \\
$0.2-4.7 \times 10^{6}$ & per apothecium & Sclerotinia trifoliorum & (Raynal, 1990) \\
$2-30 \times 10^{6}$ & per apothecium & Sclerotinia sclerotiorum & (Venette, 1998) \\
$0.2-3 \times 10^{12}$ & per ha & Sclerotinia sclerotiorum & (Venette, 1998) \\
& & Basidiomycota & \\
$4 \times 10^{7}$ & per fruiting body and hour & Psalliota campestris & (Buller, 1909) \\
$1 \times 10^{8}$ & per fruiting body and hour & Coprinus comatus & (Buller, 1909) \\
$1-10 \times 10^{10}$ & per fruiting body and year & Polyporus squamosus & (Buller, 1909) \\
$6.8 \times 10^{8}$ & per fruiting body and week & Daedalea confragosa & (Buller, 1909) \\
$3 \times 10^{10}$ & per fruiting body and day & Ganoderma applanatum & (Meredith, 1973) \\
\hline
\end{tabular}


Table A2. Number concentrations of actively wet discharged ascospores, AAS (a), and actively wet discharged basidiospores, ABS (b), observed in ambient air.

\begin{tabular}{|c|c|c|c|}
\hline $\begin{array}{l}\text { (a) } \\
\text { AAS Concentration } \\
\left(10^{3} \mathrm{~m}^{-3}\right)\end{array}$ & Species & Location and Time & References \\
\hline $0-39$ & Monilinia fructicola & Hastings, NZ (August-September) & (Tate and Wood, 2000) ${ }^{a}$ \\
\hline $0.1-9.3$ & Gibberella zeae & Quebec, Canada (July) & $\left(\right.$ Paulitz, 1996) ${ }^{\mathrm{b}}$ \\
\hline $0-15.2$ & Gibberella zeae & Manitoba, Canada (July-August) & (Inch et al., 2005) \\
\hline $0.01-1.5$ & Gibberella zeae & Ottawa, Canada (June-July) & (Fernando et al., 2000) \\
\hline$\leq 2.0$ & Leptosphaeria & Ontario, Canada (May-October) & (Li and Kendrick, 1995) \\
\hline $0.04-2.1$ & Venturia inaequalis & Ontario, Canada (April-May) & (Warner and Braun, 1992) \\
\hline 7.4 & Sclerotinia sclerotiorum & USA & (Venette, 1998) \\
\hline $0.1-1$ & Gibberella zeae & Pennsylvania, USA (April-October) & Ayers et al. 1975, cited by (Paulitz, 1996) \\
\hline$\leq 2.5$ & various & Rochester, USA (April-September) & (Decco et al., 1998) \\
\hline$\overline{0} .5-2.2$ & various & Oklahoma, USA (September) & (Sterling et al., 1999) \\
\hline $0.1-45$ & various & Oklahoma, USA (May) & (Troutt and Levetin, 2001) \\
\hline $0.1-15.6$ & Venturia inaequalis & Southeastern Norway (April-June) & (Stensvand et al., 1998) \\
\hline$\leq 0.6$ & various & Derby, UK (January-December) & (Newson et al., 2000) \\
\hline$\leq 2000$ & Didymella exitialis & Blandford, UK (August) & (Frankland and Gregory, 1973) \\
\hline$\leq 4.4$ & Didymella exitialis & Edinburgh, UK (July-October) & (Richardson, 1996) \\
\hline $0.03-5.9$ & Venturia inaequalis & Northern Italy (March-April) & (Rossi et al., 2003) \\
\hline $0-14.3$ & Pleospora allii & Cordoba, Spain (March-May) & (Prados-Ligero et al., 2003) \\
\hline$\leq 90$ & Phyllachora maydis & Poza Rica, Mexico (February-April) & (Hock et al., 1995) ${ }^{b}$ \\
\hline$\overline{2.5}-3.3$ & various & Taiwan (September-April) & (Wu et al., 2004) \\
\hline $2-23$ & various & Caxias do Sul, Brazil (January-December) & (Zoppas et al., 2006) \\
\hline 7.4 & various & Balbina, Brazil (July) & this work \\
\hline \multicolumn{4}{|c|}{ a original data normalized by time; ${ }^{\mathrm{b}}$ data from infested plots. } \\
\hline \multicolumn{4}{|l|}{ (b) } \\
\hline $\begin{array}{l}\text { ABS Concentration } \\
\left(10^{3} \mathrm{~m}^{-3}\right)\end{array}$ & Species & Location and Time & References \\
\hline$\leq 2.8$ & various & Ontario, Canada (May-October) & (Li and Kendrick, 1995) \\
\hline$\overline{0}-0.05$ & Rusts & Rochester, USA (April-September) & (Decco et al., 1998) \\
\hline $0-0.25$ & Smuts & Rochester, USA (April-September) & (Decco et al., 1998) \\
\hline $0-0.5$ & various & Rochester, USA (April-September) & (Decco et al., 1998) \\
\hline $0.1-5.5$ & various & Oklahoma, USA (May) & (Troutt and Levetin, 2001) \\
\hline $0.6-1.6$ & various & Oklahoma, USA (September) & (Sterling et al., 1999) \\
\hline$\leq 3$ & various & Oklahoma, USA (May-November) & (Levetin, 1990) \\
\hline$\leq 30$ & various & Harpenden, UK (July-September) & (Gregory and Hirst, 1952) \\
\hline$\overline{0.3}-1000$ & various & Chichester, UK (July) & (Gregory and Sreeramulu, 1958) \\
\hline$\leq 10$ & various & Cardiff, UK (June-October) & (Adams et al., 1968) \\
\hline$\overline{5} .4$ & various & Derby, UK (January-December) & (Newson et al., 2000) \\
\hline$\leq 3$ & various & Bern, Switzerland (June-October) & (Helbling et al., 2002) \\
\hline $0.5-6$ & various & Saudi Arabia (January-December) & (Hasnain et al., 2005) \\
\hline $0-0.15$ & Rusts & Saudi Arabia (January-December) & (Hasnain et al., 2005) \\
\hline $0.5-4$ & Smuts & Saudi Arabia (January-December) & (Hasnain et al., 2005) \\
\hline$\leq 4.6$ & various & Mexico City, Mexico (January-November) & (Calderon et al., 1995) \\
\hline $1.3-2.9$ & various & Taiwan (April-September) & (Wu et al., 2004) \\
\hline 0.06 & Rusts & Taiwan (September-April) & (Wu et al., 2004) \\
\hline 0.5 & Smuts & Taiwan (September-April) & (Wu et al., 2004) \\
\hline $2.5-24$ & various & Caxias do Sul, Brazil (January-December) & (Zoppas et al., 2006) \\
\hline 3.6 & Rusts & Balbina, Brazil (July) & this work \\
\hline 9.2 & Smuts & Balbina, Brazil (July) & this work \\
\hline
\end{tabular}


Table A3. Mannitol mass concentrations in ambient air observed for different ranges of aerosol particle size (aerodynamic diameter), sampling locations, and seasons.

\begin{tabular}{|c|c|c|c|c|}
\hline $\begin{array}{l}\text { Average } \\
\text { Concentration } \\
\left(\mathrm{ng} \mathrm{m}^{-3}\right)\end{array}$ & $\begin{array}{l}\text { Concentration } \\
\text { Range } \\
\left(\mathrm{ng} \mathrm{m}^{-3}\right)\end{array}$ & $\begin{array}{l}\text { Particle } \\
\text { Diameter } \\
(\mu \mathrm{m})\end{array}$ & Location and Time & References \\
\hline \multicolumn{5}{|c|}{ Extratropical } \\
\hline 0.7 & $0.5-1.3$ & $\leq 1$ & Hyytiälä, Finland (fall) & (Kourtchev et al., 2005a) \\
\hline 1.9 & $1.2-3.4$ & $\leq 1$ & Hyytiälä, Finland (summer) & (Kourtchev et al., 2005a) \\
\hline 10.1 & $1.3-29$ & $\leq 2.5$ & K-puszta, Hungary (summer, day) & (Ion et al., 2005) \\
\hline 2.3 & $0.6-12$ & $\leq 2.5$ & K-puszta, Hungary (summer, night) & (Ion et al., 2005) \\
\hline 10.7 & $5.4-26$ & $\leq 2.5$ & Jülich, Germany (summer) & (Kourtchev et al., 2005b) \\
\hline- & $3-66$ & $\leq 7$ & Kobe City, Japan & (Suzuki et al., 2001) \\
\hline- & $1.6-23$ & $\leq 10$ & Melpitz, Germany (spring) & (Carvalho et al., 2003) \\
\hline- & $0.5-88$ & $\leq 10$ & Hyytiälä, Finland (summer) & (Carvalho et al., 2003) \\
\hline 4.3 & $0-10$ & $\leq 10$ & Birkenes, Norway & (Yttri et al., 2007) \\
\hline 8.1 & $1.1-19$ & $\leq 10$ & Oslo, Norway & (Yttri et al., 2007) \\
\hline 20.0 & $9-30$ & $\leq 10$ & Oslo, Norway & (Yttri et al., 2007) \\
\hline 26.0 & $7.8-70$ & $\leq 10$ & Ghent, Belgium (winter) & (Pashynska et al., 2002) \\
\hline 97.0 & $31-220$ & $\leq 10$ & Ghent, Belgium (summer) & (Pashynska et al., 2002) \\
\hline 4.2 & $0.9-14$ & $0.06-16$ & Elverum, Norway (winter) & (Yttri et al., 2007) \\
\hline 18.0 & $12-24$ & $0.06-16$ & Elverum, Norway (summer) & (Yttri et al., 2007) \\
\hline- & $0.9-10.2$ & $\geq 1.0$ & Maine, USA & (Medeiros et al., 2006) \\
\hline \multicolumn{5}{|c|}{ Tropical (Brazil), Wet Season } \\
\hline 22.3 & $4.7-56$ & $\leq 2.5$ & Reserva Biologica Jarú, Rondônia (1999) & (Graham et al., 2002) \\
\hline 26.3 & $9.9-50$ & $\leq 2.5$ & FNS, Rondônia (1999) & (Graham et al., 2002) \\
\hline 20.8 & $11-31$ & $\leq 2.5$ & FNS, Rondônia (2002) & (Decesari et al., 2006) \\
\hline 9.4 & - & $\leq 2.5$ & Balbina, Amazonas (day) (2001) & (Claeys et al., 2004) \\
\hline 8.4 & - & $\leq 2.5$ & Balbina, Amazonas (night) (2001) & (Claeys et al., 2004) \\
\hline $15.2^{\mathrm{a}}$ & $9.6-24$ & $\leq 2.5$ & Balbina, Amazonas (2001) & (Graham et al., 2003b) \\
\hline 13.0 & - & $\leq 2.5$ & Balbina, Amazonas (day) (2001) & (Graham et al., 2003b) \\
\hline 17.0 & - & $\leq 2.5$ & Balbina, Amazonas (night) (2001) & (Graham et al., 2003b) \\
\hline 112.0 & $58-330$ & $\mathrm{TSP}^{\mathrm{b}}$ & Balbina, Amazonas (1998) & (Claeys et al., 2004) \\
\hline 32.0 & - & $\geq 2.5$ & Balbina, Amazonas (day) (2001) & (Claeys et al., 2004) \\
\hline 68.0 & - & $\geq 2.5$ & Balbina, Amazonas (night) (2001) & (Claeys et al., 2004) \\
\hline $53.3^{\mathrm{a}}$ & $24-102$ & $\geq 2.5$ & Balbina, Amazonas (2001) & (Graham et al., 2003b) \\
\hline 29.0 & - & $\geq 2.5$ & Balbina, Amazonas (day) (2001) & (Graham et al., 2003b) \\
\hline 78.0 & - & $\geq 2.5$ & Balbina, Amazonas (night) (2001) & (Graham et al., 2003b) \\
\hline
\end{tabular}

a average of campaign (19-28 July 2001); ${ }^{\mathrm{b}}$ TSP: total suspended particles. 
Table A4. Hexose (glucose \& fructose) mass concentrations in ambient air observed for different ranges of aerosol particle size (aerodynamic diameter), sampling locations, and seasons.

\begin{tabular}{|c|c|c|c|c|c|}
\hline Substance & $\begin{array}{l}\text { Average } \\
\text { Concentration } \\
\left(\mathrm{ng} \mathrm{m}^{-3}\right)\end{array}$ & $\begin{array}{l}\text { Concentration } \\
\text { Range } \\
\left(\mathrm{ng} \mathrm{m}^{-3}\right)\end{array}$ & $\begin{array}{l}\text { Particle Diameter } \\
(\mu \mathrm{m})\end{array}$ & Location and Time & References \\
\hline \multicolumn{6}{|c|}{ Extratropical } \\
\hline Glc & - & $3.1-50$ & $\geq 1.0$ & Maine, USA & (Medeiros et al., 2006) \\
\hline Glc & - & $5.4-15$ & $\geq 2.5$ & San Joaquin Valley, California, USA & (Nolte et al., 2001) \\
\hline Glc & 15 & $11-26$ & $\leq 2.5$ & Jülich, Germany (summer) & (Kourtchev et al., 2005b) \\
\hline Glc & - & $1.3-41$ & $\leq 10$ & Hyytiälä, Finland (summer) & (Carvalho et al., 2003) \\
\hline Glc & 3.7 & $0.9-7.2$ & $\leq 10$ & Birkenes, Norway & (Yttri et al., 2007) \\
\hline Glc & 47 & $8.4-93$ & $\leq 10$ & Oslo, Norway & (Yttri et al., 2007) \\
\hline Glc & 22 & $5.4-32$ & $\leq 10$ & Elverum, Norway (winter) & (Yttri et al., 2007) \\
\hline Glc & 19 & $10-34$ & $\leq 10$ & Elverum, Norway (summer) & (Yttri et al., 2007) \\
\hline Glc & - & $28-180$ & $\leq 10$ & Melpitz, Germany (spring) & (Carvalho et al., 2003) \\
\hline Glc & 73 & $30-153$ & $\leq 10$ & Ghent, Belgium (winter) & (Pashynska et al., 2002) \\
\hline Glc & 270 & $110-610$ & $\leq 10$ & Ghent, Belgium (summer) & (Pashynska et al., 2002) \\
\hline Fru & - & $0.1-5.3$ & $\geq 1.0$ & Maine, USA & (Medeiros et al., 2006) \\
\hline Fru & 10 & $6-20$ & $\leq 2.5$ & Jülich, Germany (summer) & (Kourtchev et al., 2005b) \\
\hline Fru & 1.4 & $0.3-3.9$ & $\leq 10$ & Birkenes, Norway & (Yttri et al., 2007) \\
\hline Fru & 42 & $4.6-90$ & $\leq 10$ & Oslo, Norway & (Yttri et al., 2007) \\
\hline Fru & 11 & $3.4-21$ & $\leq 10$ & Elverum, Norway (winter) & (Yttri et al., 2007) \\
\hline Fru & 11 & $3.3-25$ & $\leq 10$ & Elverum, Norway (summer) & (Yttri et al., 2007) \\
\hline Fru & 37 & $10-126$ & $\leq 10$ & Ghent, Belgium (winter) & (Pashynska et al., 2002) \\
\hline Fru & 193 & $39-440$ & $\leq 10$ & Ghent, Belgium (summer) & (Pashynska et al., 2002) \\
\hline \multicolumn{6}{|c|}{ Tropical (Brazil), Wet Season } \\
\hline Glc \& Fru & 32.4 & $6.9-64$ & $\leq 2.5$ & Reserva Biologica Jarú, Rondônia (1999) & (Graham et al., 2002) \\
\hline Glc \& Fru & 48.6 & $17-82$ & $\leq 2.5$ & FNS, Rondônia (1999) & (Graham et al., 2002) \\
\hline Fru & 4.0 & $2.5-5.9$ & $\leq 2.5$ & FNS, Rondônia (2002) & (Decesari et al., 2006) \\
\hline Glc & 15.6 & - & $\leq 2.5$ & Balbina, Amazonas (day) (2001) & (Claeys et al., 2004) \\
\hline Glc & 0.6 & - & $\leq 2.5$ & Balbina, Amazonas (night) (2001) & (Claeys et al., 2004) \\
\hline Glc \& Fru & $12.6^{\mathrm{a}}$ & $3.6-26$ & $\leq 2.5$ & Balbina, Amazonas (2001) & (Graham et al., 2003b) \\
\hline Glc \& Fru & 20 & - & $\leq 2.5$ & Balbina, Amazonas (day) (2001) & (Graham et al., 2003b) \\
\hline Glc \& Fru & 5.9 & - & $\leq 2.5$ & Balbina, Amazonas (night) (2001) & (Graham et al., 2003b) \\
\hline Glc & 29 & $12-76$ & TSP & Balbina, Amazonas (1998) & (Claeys et al., 2004) \\
\hline Glc & 134 & - & $\geq 2.5$ & Balbina, Amazonas (day) (2001) & (Claeys et al., 2004) \\
\hline Glc & 2.7 & - & $\geq 2.5$ & Balbina, Amazonas (night) (2001) & (Claeys et al., 2004) \\
\hline Glc \& Fru & $76.7^{\mathrm{a}}$ & $3.6-200$ & $\geq 2.5$ & Balbina, Amazonas (2001) & (Graham et al., 2003b) \\
\hline Glc \& Fru & 146 & - & $\geq 2.5$ & Balbina, Amazonas (day) (2001) & (Graham et al., 2003b) \\
\hline Glc \& Fru & 7.2 & - & $\geq 2.5$ & Balbina, Amazonas (night) (2001) & (Graham et al., 2003b) \\
\hline
\end{tabular}

a average of campaign (19-28 July 2001) 
Table A5. Potassium mass concentrations in ambient air observed for different ranges of aerosol particle size (aerodynamic diameter) during the wet season in Brazil.

\begin{tabular}{|c|c|c|c|}
\hline $\begin{array}{l}\text { Average Concentration } \\
\left(\mathrm{ng} \mathrm{m}^{-3}\right)\end{array}$ & $\begin{array}{l}\text { Particle Diameter } \\
(\mu \mathrm{m})\end{array}$ & Location and Time & References \\
\hline 24.0 & $0.05-1.2$ & FNS, Rondônia (day) & (Fuzzi et al., 2007) \\
\hline 68.0 & $0.05-1.2$ & FNS, Rondônia (night) & (Fuzzi et al., 2007) \\
\hline 33.5 & $\leq 2$ & FNS, Rondônia & (Artaxo et al., 2002) \\
\hline 26.2 & $\leq 2$ & Reserva Biologica Jarú, Rondônia & (Artaxo et al., 2002) \\
\hline 27.1 & $\leq 2$ & Reserva Biologica Jarú, Rondônia & (Guyon et al., 2003) \\
\hline 32.1 & $\leq 2$ & Ducke Forest Reserve, Amazonas (Meteorological Site) & (Artaxo et al., 1990) \\
\hline 26.3 & $\leq 2$ & Ducke Forest Reserve, Amazonas (Tower Site) & (Artaxo et al., 1990) \\
\hline 24.2 & $\leq 2$ & ZF1 site, Amazonas & (Artaxo et al., 1990) \\
\hline 18.0 & $\leq 2$ & Balbina, Amazonas & (Formenti et al., 2001) \\
\hline 29.2 & $\leq 2$ & Balbina, Amazonas & (Graham et al., 2003a) \\
\hline 94.0 & $\leq 2$ & Alta Floresta, Mato Grosso & (Echalar et al., 1998) \\
\hline 220.0 & $\leq 2$ & Alta Floresta, Mato Grosso & (Maenhaut et al., 2002) \\
\hline 14.0 & $1.2-10$ & FNS, Rondônia (day) & (Fuzzi et al., 2007) \\
\hline 49.0 & $1.2-10$ & FNS, Rondônia (night) & (Fuzzi et al., 2007) \\
\hline 76.7 & $2-10$ & FNS, Rondônia & (Artaxo et al., 2002) \\
\hline 73.7 & $2-10$ & Reserva Biologica Jarú, Rondônia & (Artaxo et al., 2002) \\
\hline 107.6 & $2-10$ & Reserva Biologica Jarú, Rondônia & (Guyon et al., 2003) \\
\hline 112.1 & $2-15$ & Ducke Forest Reserve, Amazonas (Meteorological Site) & (Artaxo et al., 1990) \\
\hline 94.6 & $2-15$ & Ducke Forest Reserve, Amazonas (Tower Site) & (Artaxo et al., 1990) \\
\hline 87.3 & $2-15$ & ZF1 site, Amazonas & (Artaxo et al., 1990) \\
\hline 69.0 & $2-10$ & Balbina, Amazonas & (Formenti et al., 2001) \\
\hline 52.6 & $2-10$ & Balbina, Amazonas & (Graham et al., 2003a) \\
\hline 270.0 & $2-10$ & Alta Floresta, Mato Grosso & (Echalar et al., 1998) \\
\hline 240.0 & $2-10$ & Alta Floresta, Mato Grosso & (Maenhaut et al., 2002) \\
\hline
\end{tabular}

Table A6. Chloride mass concentrations in ambient air observed for different ranges of aerosol particle size (aerodynamic diameter) during the wet season in Amazonia.

\begin{tabular}{llll}
\hline $\begin{array}{l}\text { Average Concentration } \\
\left(\mathrm{ng} \mathrm{m}^{-3}\right)\end{array}$ & $\begin{array}{l}\text { Particle Diameter } \\
(\mu \mathrm{m})\end{array}$ & Location and Time & References \\
\hline 5.5 & $\leq 2$ & FNS, Rondônia & (Artaxo et al., 2002) \\
5.1 & $\leq 2$ & Reserva Biologica Jarú, Rondônia & (Artaxo et al., 2002) \\
9.5 & $\leq 2$ & Ducke Forest Reserve, Amazonas (Meteorological Site) & (Artaxo et al., 1990) \\
13.0 & $\leq 2$ & Ducke Forest Reserve, Amazonas (Tower Site) & (Artaxo et al., 1990) \\
8.9 & $\leq 2$ & ZF1 site, Amazonas & (Artaxo et al., 1990) \\
65.0 & $\leq 2$ & Balbina, Amazonas & (Formenti et al., 2001) \\
4.8 & $\leq 2$ & Balbina, Amazonas & (Graham et al., 2003a) \\
2.3 & $\leq 2$ & Alta Floresta, Mato Grosso & (Echalar et al., 1998) \\
37.0 & $\leq 2$ & Alta Floresta, Mato Grosso & (Maenhaut et al., 2002) \\
14.3 & $2-10$ & FNS, Rondônia & (Artaxo et al., 2002) \\
9.4 & $2-10$ & Reserva Biologica Jarú, Rondônia & (Artaxo et al., 2002) \\
7.8 & $2-10$ & Reserva Biologica Jarú, Rondônia & (Guyon et al., 2003) \\
55.0 & $2-15$ & Ducke Forest Reserve, Amazonas (Meteorological Site) & (Artaxo et al., 1990) \\
33.2 & $2-15$ & Ducke Forest Reserve, Amazonas (Tower Site) & (Artaxo et al., 1990) \\
52.5 & $2-15$ & ZF1 site, Amazonas & (Artaxo et al., 1990) \\
155.0 & $2-10$ & Balbina, Amazonas & (Formenti et al., 2001) \\
59.1 & $2-10$ & Balbina, Amazonas & (Graham et al., 2003a) \\
41.0 & $2-10$ & Alta Floresta, Mato Grosso & (Echalar et al., 1998) \\
65.0 & $2-10$ & Alta Floresta, Mato Grosso & (Maenhaut et al., 2002) \\
\hline
\end{tabular}


Table A7. Total particulate matter mass concentrations in ambient air observed for particles with aerodynamic diameters of 1-2 $\mu \mathrm{m}$ to 10-15 $\mu \mathrm{m}$ during the wet season in Amazonia.

\begin{tabular}{llll}
\hline $\begin{array}{l}\text { Mass Concentration } \\
\left(\mathrm{ng} \mathrm{m}^{-3}\right)\end{array}$ & $\begin{array}{l}\text { Particle Diameter } \\
(\mu \mathrm{m})\end{array}$ & Location and Time & References \\
\hline 1.0 & $1.2-10$ & FNS, Rondônia, (DLPI, day) & (Fuzzi et al., 2007) \\
4.3 & $1.2-10$ & FNS, Rondônia (DLPI, night) & (Fuzzi et al., 2007) \\
1.8 & $1.2-10$ & FNS, Rondônia (MOUDI, day) & (Fuzzi et al., 2007) \\
6.9 & $1.2-10$ & FNS, Rondônia (MOUDI, night) & (Fuzzi et al., 2007) \\
5.7 & $2-10$ & FNS, Rondônia & (Artaxo et al., 2002) \\
5.1 & $2-10$ & Reserva Biologica Jarú, Rondônia & (Artaxo et al., 2002) \\
6.6 & $2-10$ & Reserva Biologica Jarú, Rondônia & (Guyon et al., 2003) \\
8.0 & $2-15$ & Ducke Forest Reserve, Amazonas (Meteorological Site) & (Artaxo et al., 1990) \\
7.6 & $2-15$ & Ducke Forest Reserve, Amazonas (Tower Site) & (Artaxo et al., 1990) \\
6.5 & $2-15$ & ZF1 site, Amazonas & (Artaxo et al., 1990) \\
5.8 & $2-10$ & Balbina, Amazonas & (Formenti et al., 2001) \\
2.8 & $2-10$ & Balbina, Amazonas (day) & (Graham et al., 2003a) \\
5.5 & $2-10$ & Balbina, Amazonas (night) & (Graham et al., 2003a) \\
16.4 & $2-10$ & Alta Floresta, Mato Grosso & (Echalar et al., 1998) \\
15.1 & $2-10$ & Alta Floresta, Mato Grosso & (Maenhaut et al., 2002) \\
\hline
\end{tabular}

Acknowledgements. We gratefully acknowledge helpful comments and suggestions from C. Morris, M. Bardin, and from an anonymous referee. This study is based on results from the Large-Scale Atmosphere-Biosphere Experiment in Amazonia (LBA) and was funded by the Max Planck Society. P. Taylor acknowledges financial support by a grant from the Southern California Environmental Health Sciences Center (NIEHS 5P30 ES07048), a Boswell Fellowship from Caltech and the Huntington Medical Research Institute. P. Taylor also thanks R. C. Flagan, Caltech, and E. Newbigin, University of Melbourne. Special thanks are due to T. W. Andreae for help with the preparation of the manuscript.

Edited by: A. B. Guenther

\section{References}

Adams, K. F., Hyde, H. A., and Williams, D. A.: Woodlands as a source of allergens with special reference to basidiospores, Acta Allergologica, 23, 265-281, 1968.

Andreae, M. O., Artaxo, P., Brandão, C., Carswell, F. E., Ciccioli, P., da Costa, A. L., Culf, A. D., Esteves, J. L., Gash, J. H. C., Grace, J., Kabat, P., Lelieveld, J., Malhi, Y., Manzi, A. O., Meixner, F. X., Nobre, A. D., Nobre, C., Ruivo, M. d. L. P., Silva-Dias, M. A., Stefani, P., Valentini, R., von Jouanne, J., and Waterloo, M. J.: Biogeochemical cycling of carbon, water, energy, trace gases and aerosols in Amazonia: The LBA-EUSTACH experiments, J. Geophys. Res., 107, 8066, doi:10.1029/2001JD000524, 2002.

Andreae, M. O. and Crutzen, P. J.: Atmospheric aerosols: Biogeochemical sources and role in atmospheric chemistry, Science, 276, 1052-1058, 1997.

Ariya, P. A. and Amyot, M.: New Directions: The role of bioaerosols in atmospheric chemistry and physics, Atmos. En- viron., 38, 1231-1232, 2004.

Artaxo, P. and Hansson, H.-C.: Size distribution of biogenic aerosol particles from the Amazon basin, Atmos. Environ., 29, 393-402, 1995.

Artaxo, P., Maenhaut, W., Storms, H., and Grieken, R. V.: Aerosol characteristics and sources for the Amazon Basin during the wet season, J. Geophys. Res., 95, 16971-16986, 1990.

Artaxo, P., Martins, J. V., Yamasoe, M. A., Procopio, A. S., Pauliquevis, T. M., Andreae, M. O., Guyon, P., Gatti, L. V., and Leal, A. M. C.: Physical and chemical properties of aerosols in the wet and dry seasons in Rondonia, Amazonia, J. Geophys. Res., 107, 8081, doi:10.1029/2001JD000666, 2002.

Aylor, D. E. and Flesch, T. K.: Estimating spore release rates using a Lagrangian stochastic simulation model, J. Appl. Meteorol., 40, 1196-1208, 2001.

Aylor, D. E., Fry, W. E., Mayton, H., and Andrade-Piedra, J. L.: Quantifying the rate of release and escape of Phytophthora infestans sporangia from a potato canopy, Phytopathology, 91, 11891196, 2001.

Bai, F. Y., Takashima, M., Jia, J. H., and Nakase, T.: Dioszegia zsoltii sp nov, a new ballistoconidium-forming yeast species with two varieties, J. General Appl. Microbiol., 48, 17-23, 2002.

Barnett, J. A. and Robinow, C. F.: A history of research on yeasts 4: cytology part I, 1890-1950, Yeast, 19, 151-182, 2002.

Bauer, H., Kasper-Giebl, A., Loflund, M., Giebl, H., Hitzenberger, R., Zibuschka, F., and Puxbaum, H.: The contribution of bacteria and fungal spores to the organic carbon content of cloud water, precipitation and aerosols, Atmos. Res., 64, 109-119, 2002.

Bauer, H., Weinke, G., Scheller, L., Berger, A., Kasper-Giebel, A., Puxbaum, H., Vermeylen, R., Claeys, M., and Maenhaut, W.: Contribution of bioaerosols to organic carbon in urban-fringe aerosols, European Aerosol Conference, 2005.

Bauer, R. and Oberwinkler, F.: The Ustomycota: An inventory, Mycotaxon, 64, 303-319, 1997.

Beauford, W., Barber, J., and Barringer, A. R.: Heavy metal release 
from plants into the atmosphere, Nature, 256, 35-37, 1975.

Boekhout, T.: A revision of ballistoconidia-forming yeasts and fungi, Studies in Mycology, 33, 1-194, 1991.

Boreson, J., Dillner, A. M., and Peccia, J.: Correlating bioaerosol load with PM2.5 and PM10cf concentrations: a comparison between natural desert and urban-fringe aerosols, Atmos. Environ., 38, 6029-6041, 2004.

Brown, J. K. M. and Hovmoller, M. S.: Epidemiology - Aerial dispersal of pathogens on the global and continental scales and its impact on plant disease, Science, 297, 537-541, 2002.

Buller, A. H. R.: Researches on fungi, Longmans, Green and Co., London, 1909.

Buller, A. H. R.: Researches on fungi, Longmans, Green and Co., London, 1909-1950.

Buller, A. H. R.: Die Erzeugung und Befreiung der Sporen bei Coprinus sterquilinus, Jahrbücher für wissenschaftliche Botanik, 56, 299-329, 1915.

Buller, A. H. R.: Researches on fungi, Longmans, Green and Co., London, 1922.

Buller, A. H. R.: Physiological studies of fungi, Nature, 134, 291291, 1934

Buller, A. H. R. and Vanterpool, T. C.: Violent spore-discharge in Tilletia tritic, Nature, 116, 934-935, 1925.

Burch, M. and Levetin, E.: Effects of meteorological conditions on spore plumes, Int. J. Biometeorol., 46, 107-117, 2002.

Burge, H. A.: An update on pollen and fungal spore aerobiology, Journal of Allergy and Clinical Immunology, 110, 544-552, 2002.

Butinar, L., Spencer-Martins, I., and Gunde-Cimerman, N.: Yeasts in high Arctic glaciers: the discovery of a new habitat for eukaryotic microorganisms, Antonie Van Leeuwenhoek, 91, 277-289, 2007.

Byrne, J. M., Hausbeck, M. K., and Shaw, B. D.: Factors affecting concentrations of airborne conidia of Oidium sp. among poinsettias in a greenhouse, Plant Disease, 84, 1089-1095, 2000.

Calderon, C., Lacey, J., McCartney, H. A., and Rosas, I.: Seasonal and diurnal variation of airborne basidiomycete spore concentrations in Mexico City, Grana, 34, 260-268, 1995.

Carlile, M. J., Watkinson, S. C., and Gooday, G. W.: The Fungi, Elsevier Ltd., Amsterdam, 2001.

Carvalho, A., Pio, C., and Santos, C.: Water-soluble hydroxylated organic compounds in German and Finnish aerosols, Atmos. Environ., 37, 1775-1783, 2003.

Chatterjee, J. and Hargreave, F. E.: Atmospheric pollen and fungal spores in Hamilton in 1972 estimated by the Hirst automatic volumetric spore trap, Canadian Medical Association Journal, 110, 659-663, 1974.

Claeys, M., Graham, B., Vas, G., Wang, W., Vermeylen, R., Pashynska, V., Cafmeyer, J., Guyon, P., Andreae, M. O., Artaxo, P., and Maenhaut, W.: Formation of secondary organic aerosols through photooxidation of isoprene, Science, 303, 1173-1176, 2004.

Couch, J. N.: A new Conidiobulus with sexual reproduction, Am. J. Botany, 26, 119-130, 1939.

Cox, C. S. and Wathes, C. M.: Bioaerosol Handbook, CRC Lewis Publishers, Boca Raton, 1995.

Davoli, P. and Weber, R. W. S.: Carotenoid pigments from the red mirror yeast Sporobolomyces roseus, Mycologist, 16, 102-108, 2002.

de Garcia, V., Brizzio, S., Libkind, D., Buzzini, P., and van Broock,
M.: Biodiversity of cold-adapted yeasts from glacial meltwater rivers in Patagonia, Argentina, FEMS Microbiology Ecology, 59, 331-341, 2007.

de Jong, M. D., Bourdot, G. W., and Powell, J.: A model of the escape of Sclerotinia sclerotiorum ascospores from pasture, Ecol. Modell., 150, 83-105, 2002.

Decco, M. L., Wendland, B. I., and O'Connell, E. J.: Volumetric assessment of airborne pollen and spore levels in Rochester, Minnesota, 1992 through 1995, Mayo Clinic Proceedings, 73, 225-229, 1998.

Decesari, S., Fuzzi, S., Facchini, M. C., Mircea, M., Emblico, L., Cavalli, F., Maenhaut, W., Chi, X., Schkolnik, G., Falkovich, A., Rudich, Y., Claeys, M., Pashynska, V., Vas, G., Kourtchev, I., Vermeylen, R., Hoffer, A., Andreae, M. O., Tagliavini, E., Moretti, F., and Artaxo, P.: Characterization of the organic composition of aerosols from Rondonia, Brazil, during the LBASMOCC 2002 experiment and its representation through model compounds, Atmos. Chem. Phys., 6, 375-402, 2006, http://www.atmos-chem-phys.net/6/375/2006/.

Després, V., Nowoisky, J., Klose, M., Conrad, R., Andreae, M. O., and Pöschl, U.: Molecular genetics and diversity of primary biogenic aerosol particles in urban, rural, and high-alpine air, Biogeosciences Discuss., 4, 349-384, 2007, http://www.biogeosciences-discuss.net/4/349/2007/.

Dingle, A. N.: Pollens as condensation nuclei, Journal de Recherches Atmosphériques, 2, 231-237, 1966.

Dusek, U., Frank, G. P., Hildebrandt, L., Curtius, J., Schneider, J., Walter, S., Chand, D., Drewnick, F., Hings, S., Jung, D., Borrmann, S., and Andreae, M. O.: Size matters more than chemistry for cloud-nucleating ability of aerosol particles, Science, 312, 1375-1378, 2006.

Echalar, F., Artaxo, P., Martins, J. V., Yamasoe, M., Gerab, F., Maenhaut, W., and Holben, B.: Long-term monitoring of atmospheric aerosols in the Amazon Basin: Source identification and apportionment, J. Geophys. Res., 103, 31 849-31 864, 1998.

Ehrenberg, C. G.: Neue Beobachtungen über blutartige Erscheinungen in Aegypten, Arabien und Sibirien, nebst einer Uebersicht und Kritik der früher bekannten, Annalen der Physik und Chemie, 94, 477-514, 1830.

Elbert, W.: Interactive comment on "Contribution of fungi to primary biogenic aerosols in the atmosphere: active discharge of spores, carbohydrates, and inorganic ions by Asco- and Basidiomycota" by W. Elbert et al., Atmos. Chem. Phys. Discuss., 6, S5329-S5331, 2006.

Fang, Z., Ouyang, Z., Hu, L., Wang, X., Zheng, H., and Lin, X.: Culturable airborne fungi in outdoor environments in Beijing, China, Science of The Total Environment, 350, 47-58, 2005.

Fernando, W. G. D., Miller, J. D., Seaman, W. L., Seifert, K., and Paulitz, T. C.: Daily and seasonal dynamics of airborne spores of Fusarium graminearum and other Fusarium species sampled over wheat plots, Canadian Journal of Botany, 78, 497-505, 2000.

Fischer, M., Cox, J., Davis, D. J., Wagner, A., Taylor, R., Huerta, A. J., and Money, N. P.: New information on the mechanism of forcible ascospore discharge from Ascobolus immersus, Fungal Genetics and Biology, 41, 972-972, 2004.

Fish, B. R.: Electrical generation of natural aerosols from vegetation, Science, 175, 1239-1240, 1972.

Formenti, P., Andreae, M. O., Lange, L., Roberts, G., Cafmeyer, J., 
Rajta, I., Maenhaut, W., Holben, B. N., Artaxo, P., and Lelieveld, J.: Saharan dust in Brazil and Suriname during the Large-Scale Biosphere-Atmosphere Experiment in Amazonia (LBA) - Cooperative LBA Regional Experiment (CLAIRE) in March 1998, J. Geophys. Res., 106, 14919-14 934, 2001.

Frankland, A. W. and Gregory, P. H.: Allergenic and agricultural implications of airborne ascospore concentrations from a fungus, Didymella exitialis, Nature, 245, 336-337, 1973.

Franze, T., Weller, M. G., Niessner, R., and Pöschl, U.: Protein nitration by polluted air, Environ. Sci. Technol., 39, 1673-1678, 2005.

Fuzzi, S., Andreae, M. O., Huebert, B. J., Kulmala, M., Bond, T. C., Boy, M., Doherty, S. J., Guenther, A., Kanakidou, M., Kawamura, K., Kerminen, V. M., Lohmann, U., Russell, L. M., and Poschl, U.: Critical assessment of the current state of scientific knowledge, terminology, and research needs concerning the role of organic aerosols in the atmosphere, climate, and global change, Atmos. Chem. Phys., 6, 2017-2038, 2006, http://www.atmos-chem-phys.net/6/2017/2006/.

Fuzzi, S., Decesari, S., Facchini, M. C., Cavalli, F., Emblico, L., Mircea, M., Andreae, M. O., Trebs, I., Hoffer, A., Guyon, P., Artaxo, P., Rizzo, L. V., Lara, L. L., Pauliquevis, T., Maenhaut, W., Raes, N., Chi, X. G., Mayol-Bracero, O. L., Soto-Garcia, L. L., Claeys, M., Kourtchev, I., Rissler, J., Swietlicki, E., Tagliavini, E., Schkolnik, G., Falkovich, A. H., Rudich, Y., Fisch, G., and Gatti, L. V.: Overview of the inorganic and organic composition of size-segregated aerosol in Rondonia, Brazil, from the biomass-burning period to the onset of the wet season, J. Geophys. Res., 112, D01201, doi:10.1029/2005JD006741, 2007.

Gadanho, M., Almeida, J., and Sampaio, J. P.: Assessment of yeast diversity in a marine environment in the south of portugal by microsatellite-primed PCR, Antonie Van Leeuwenhoek, 84, 217-227, 2003.

Gilbert, G. S. and Reynolds, D. R.: Nocturnal fungi: Airborne spores in the canopy and understory of a tropical rain forest, Biotropica, 37, 462-464, 2005.

Glovsky, M. M., Taylor, P. E., Esch, R., Miguel, A. G., House, J., Tran, L., and Flagan, R. C.: Respirable allergenic aerosols produced from pollen and molds, in: Asthma: From Genes to Clinical Management, edited by: Sepiashvili, R., Monduzzi Editore, Bologna, Italy, 155-160, 2003.

Golubev, W. I.: Mastigobasidium, a new teleomorphic genus for the perfect state of ballistosporous yeast Bensingtonia intermedia, International Journal of Systematic Bacteriology, 49, 13011305, 1999.

Górny, R. L., Reponen, T., Willeke, K., Schmechel, D., Robine, E., Boissier, M., and Grinshpun, S. A.: Fungal fragments as indoor air biocontaminants, Appl. Environ. Microbiol., 68, 3522-3531, 2002.

Gottwald, T. R., Trocine, T. M., and Timmer, L. W.: A computercontrolled environmental chamber for the study of aerial fungal spore release, Phytopathology, 87, 1078-1084, 1997.

Graham, B., Guyon, P., Maenhaut, W., Taylor, P. E., Ebert, M., Matthias-Maser, S., Mayol-Bracero, O. L., Godoi, R. H. M., Artaxo, P., Meixner, F. X., Moura, M. A. L., Rocha, C., Van Grieken, R., Glovsky, M. M., Flagan, R. C., and Andreae, M. O.: Composition and diurnal variability of the natural Amazonian aerosol, J. Geophys. Res., 108, 4765, doi:10.1029/2003JD004049, 2003a.
Graham, B., Guyon, P., Taylor, P. E., Artaxo, P., Maenhaut, W., Glovsky, M. M., Flagan, R. C., and Andreae, M. O.: Organic compounds present in the natural Amazonian aerosol: Characterization by gas chromatography-mass spectrometry, J. Geophys. Res.-Atmos., 108, 4766, doi:10.1029/2003JD003990, 2003 b.

Graham, B., Mayol-Bracero, O. L., Guyon, P., Roberts, G. C., Decesari, S., Facchini, M. C., Artaxo, P., Maenhaut, W., Koll, P., and Andreae, M. O.: Water-soluble organic compounds in biomass burning aerosols over Amazonia - 1. Characterization by NMR and GC-MS, J. Geophys. Res., 107, 8047, doi:10.1029/2001JD000336, 2002.

Gregory, P. H.: Airborne microbes: Their significance and distribution, Proceedings of the Royal Society of London, 177, 469-483, 1971.

Gregory, P. H.: The microbiology of the atmosphere, Leonard Hill Books, Aylesbury, 1973.

Gregory, P. H.: Distribution of airborne pollen and spores and their long distance transport, Pure Appl. Geophys., 116, 309-315, 1978.

Gregory, P. H. and Hirst, J. M.: Possible role of basidiospores as air-borne allergens, Nature, 170, 414, 1952.

Gregory, P. H. and Hirst, J. M.: The summer air-spora at Rothamsted in 1952, Journal of General Microbiology, 17, 135-152, 1957.

Gregory, P. H. and Sreeramulu, T.: Air spora of an estuary, Transactions of the British Mycological Society, 41, 145-156, 1958.

Griffin, D. W.: Terrestrial microorganisms at an altitude of $20000 \mathrm{~m}$ in Earth's atmosphere, Aerobiologia, 20, 135-140, 2004.

Griffin, D. W., Garrison, V. H., Herman, J. R., and Shinn, E. A.: African desert dust in the Caribbean atmosphere: Microbiology and public health, Aerobiologia, 17, 203-213, 2001.

Guyon, P., Graham, B., Roberts, G. C., Mayol-Bracero, O. L., Maenhaut, W., Artaxo, P., and Andreae, M. O.: Incanopy gradients, composition, sources, and optical properties of aerosol over the Amazon forest, J. Geophys. Res., 108, 4591, doi:10.1029/2003JD003465, 2003.

Hamilton, W. D. and Lenton, T. M.: Spora and Gaia: How microbes fly with their clouds, Ethology Ecology and Evolution, 10, 1-16, 1998.

Hanlin, R. T.: Microcycle conidiation - A review, Mycoscience, 35, 113-123, 1994.

Hasnain, S. M., Al-Frayh, A., Khatija, F., and Al-Sedairy, S.: Airborne Ganoderma basidiospores in a country with desert environment, Grana, 43, 111-115, 2004.

Hasnain, S. M., Fatima, K., Al-Frayh, A., and Al-Sedairy, S. T.: Prevalence of airborne basidiospores in three coastal cities of Saudi Arabia, Aerobiologia, 21, 139-145, 2005.

Hawksworth, D. L.: Monitoring and safeguarding fungal resources worldwide: the need for an international collaborative MycoAction Plan, Fungal Diversity, 13, 29-45, 2003.

Hawksworth, D. L.: Limitation of dual nomenclature for pleomorphic fungi, Taxon, 53, 596-598, 2004.

Helbling, A., Brander, K. A., Horner, W. E., and Lehrer, S. B.: Allergy to basidiomycetes, In: Fungal Allergy and Pathogenicity, edited by:Breitenbach, M., Crameri, R. and Lehrer, S. B., Karger, Basel, 81, 28-47, 2002.

Hirst, J. M., Stedman, O. J., and Hogg, W. H.: Long-distance spore transport - Methods of measurement vertical spore profiles and detection of immigrant spores, Journal of General Microbiology, 
48, 329-355, 1967a.

Hirst, J. M., Stedman, O. J., and Hurst, G. W.: Long-distance spore transport - Vertical sections of spore clouds over sea, Journal of General Microbiology, 48, 357-377, 1967b.

Ho, H.-M., Rao, C. Y., Hsu, H.-H., Chiu, Y.-H., Liu, C.-M., and Chao, H. J.: Characteristics and determinants of ambient fungal spores in Hualien, Taiwan, Atmos. Environ., 39, 5839-5850, 2005.

Hock, J., Kranz, J., and Renfro, B. L.: Studies on the epidemiology of the tar spot disease complex of maize in Mexico, Plant Pathology, 44, 490-502, 1995.

Hong, C. X. and Michailides, T. J.: Effect of temperature on the discharge and germination of ascospores by apothecia of Monilinia fructicola, Plant Disease, 82, 195-202, 1998.

Høye, T. T., Post, E., Meltofte, H., Schmidt, N. M., and Forchhammer, M. C.: Rapid advancement of spring in the High Arctic, Current Biology, 17, R449-R451, 2007.

Imshenetsky, A. A., Lysenko, S. V., and Kazakov, G. A.: Upper boundary of the biosphere, Applied and Environmental Microbiology, 35, 1-5, 1978.

Inch, S., Fernando, W. G. D., and Gilbert, J.: Seasonal and daily variation in the airborne concentration of Gibberella zeae (Schw.) Petch spores in Manitoba, Canadian Journal of Plant Pathology-Revue Canadienne De Phytopathologie, 27, 357-363, 2005.

Ingold, C. T.: Fungal spores. Their liberation and dispersal, Clarendon Press, Oxford, 1971.

Ingold, C. T.: Teliospore germination in Tilletia opaca and T. sumatii and the nature of the tilletiaceous basidium, Mycological Research, 101, 281-284, 1997.

Ingold, C. T.: Active liberation of reproductive units in terrestrial fungi, Mycologist, 13, 113-116, 1999.

Ingold, C. T.: Singling of meiospores, Mycologist, 15, 86-87, 2001a.

Ingold, C. T.: Range in size and form of basidiospores and ascospores, Mycologist, 15, 165-166, 2001b.

Ion, A. C., Vermeylen, R., Kourtchev, I., Cafmeyer, J., Chi, X., Gelencsér, A., Maenhaut, W., and Claeys, M.: Polar organic compounds in rural $\mathrm{PM}_{2.5}$ aerosols from K-puszta, Hungary, during a 2003 summer field campaign: Sources and diel variations, Atmos. Chem. Phys., 5, 1805-1814, 2005, http://www.atmos-chem-phys.net/5/1805/2005/.

Jaenicke, R.: Abundance of cellular material and proteins in the atmosphere, Science, 308, 73-73, 2005.

Kanakidou, M., Seinfeld, J. H., Pandis, S. N., Barnes, I., Dentener, F. J., Facchini, M. C., Van Dingenen, R., Ervens, B., Nenes, A., Nielsen, C. J., Swietlicki, E., Putaud, J. P., Balkanski, Y., Fuzzi, S., Horth, J., Moortgat, G. K., Winterhalter, R., Myhre, C. E. L., Tsigaridis, K., Vignati, E., Stephanou, E. G., and Wilson, J.: Organic aerosol and global climate modelling: a review, Atmos. Chem. Phys., 5, 1053-1123, 2005,

http://www.atmos-chem-phys.net/5/1053/2005/.

Kellogg, C. A. and Griffin, D. W.: Aerobiology and the global transport of desert dust, Trends in Ecology \& Evolution, 21, 638-644, 2006.

Kendrick, B.: Fungi and the history of mycology, Encyclopedia of Life Sciences, 1-17, 2001.

Klironomos, J. N., Rillig, M. C., Allen, M. F., Zak, D. R., Pregitzer, K. S., and Kubiske, M. E.: Increased levels of airborne fungal spores in response to Populus tremuloides grown under elevated atmospheric CO2, Canadian Journal of Botany-Revue Canadienne De Botanique, 75, 1670-1673, 1997.

Kourtchev, I., Ruuskanen, T., Maenhaut, W., Kulmala, M., and Claeys, M.: Observation of 2-methyltetrols and related photooxidation products of isoprene in boreal forest aerosols from Hyytiälä, Finland, Atmos. Chem. Phys., 5, 2761-2770, 2005 a.

Kourtchev, I., Warnke, J., Maenhaut, W., Hoffmann, T., and Claeys, M.: Poster presentation: Characterisation of polar organic compounds in PM2.5 aerosols from Jülich, Germany, European Aerosol Conference 2005, Ghent, Belgium, 2005b.

Kramer, C. L. and Eversmeyer, M. G.: Comparisons of airspora concentrations at various sites within a 10 kilometer radius of Manhattan, Kansas, USA, Grana, 23, 117-122, 1984.

Kurtzman, C. P. and Fell, J. W.: The Yeasts, A Taxonomic Study, Elsevier, Amsterdam, 1998.

Lacey, J.: Spore dispersal - Its role in ecology and disease: The British contribution to fungal aerobiology, Mycological Research, 100, 641-660, 1996.

Levetin, E.: Studies on airborne basidiospores, Aerobiologia, 6, 177-180, 1990.

Levetin, E.: An atlas of fungal spores, Journal of Allergy and Clinical Immunology, 113, 366-368, 2004.

Li, D. W. and Kendrick, B.: A year-round outdoor aeromycological study in Waterloo, Ontario, Canada, Grana, 34, 199-207, 1995.

Lin, W. H. and Li, C. S.: Size characteristics of fungus allergens in the subtropical climate, Aerosol Science and Technology, 25, 93-100, 1996.

Linskens, H. F. and Jorde, W.: Pollentransport in großen Höhen Beobachtungen während der Fahrt mit einem Gasballon, Allergologie, 9, 55-58, 1986.

Lohmann, U. and Feichter, J.: Global indirect aerosol effects: A review, Atmos. Chem. Phys., 5, 715-737, 2005, http://www.atmos-chem-phys.net/5/715/2005/.

Ma, L. J., Rogers, S. O., Catranis, C. M., and Starmer, W. T.: Detection and characterization of ancient fungi entrapped in glacial ice, Mycologia, 92, 286-295, 2000.

Maenhaut, W., Fernandez-Jimenez, M.-T., Rajta, I., and Artaxo, P.: Two-year study of atmospheric aerosols in Alta Floresta, Brazil: Multielemental composition and source apportionment, Nuclear Instruments and Methods in Physics Research Section B: Beam Interactions with Materials and Atoms, 189, 243-248, 2002.

Mandrioli, P., Puppi, G. L., Bagni, N., and Prodi, F.: Distribution of microorganisms in hailstones, Nature, 246, 416-417, 1973.

Matthias-Maser, S., Bogs, B., and Jaenicke, R.: The size distribution of primary biological aerosol particles in cloud water on the mountain Kleiner Feldberg/Taunus (FRG), Atmos. Res., 54, 113, 2000.

Matthias-Maser, S. and Jaenicke, R.: Identification and size distribution of biological aerosol particles with radius $>0.2 \mu \mathrm{m}$, in: Nucleation and Atmospheric Aerosols, edited by: Fukuta, N. and Wagner, P. E., A. DEEPAK Publishing, 413-415, 1992.

McCarthy, M.: Dust clouds implicated in spread of infection, The Lancet, 358, 478-478, 2001.

McFiggans, G., Artaxo, P., Baltensperger, U., Coe, H., Facchini, M. C., Feingold, G., Fuzzi, S., Gysel, M., Laaksonen, A., Lohmann, U., Mentel, T. F., Murphy, D. M., O’Dowd, C. D., Snider, J. R., and Weingartner, E.: The effect of physical and chemical aerosol properties on warm cloud droplet activation, Atmos. 
Chem. Phys., 6, 2593-2649, 2006,

http://www.atmos-chem-phys.net/6/2593/2006/.

Medeiros, P. M., Conte, M. H., Weber, J. C., and Simoneit, B. R. T.: Sugars as source indicators of biogenic organic carbon in aerosols collected above the Howland Experimental Forest, Maine, Atmos. Environ., 40, 1694-1705, 2006.

Meier, F. C.: Collecting micro-organisms from the Arctic atmosphere. With field notes and material by Charles A. Lindberg., The Scientific Monthly, 40, 5-20, 1935.

Meier, F. C. and Artschwager, E.: Airplane collection of sugar-beet pollen, Science, 88, 507-508, 1938.

Meredith, D. S.: Violent spore release in some Fungi Imperfecti, Annals of Botany, 27, 39-47, 1963.

Meredith, D. S.: Significance of spore release and dispersal machanisms in plant disease epidemiology, Annual Review of Phytopathology, 11, 313-342, 1973.

Miguel, A. G., Cass, G. R., Glovsky, M. M. and Weiss, J.: Allergens in paved road dust and airborne particles, Environ. Sci. Technol., 33, 4159-4168, 1999.

Mims, C. W. and Richardson, E. A.: Ultrastructure of secondary spore formation in the rust Gymnosporangium-juniperivirginianae, Mycologia, 82, 236-242, 1990.

Mims, S. A. and Mims, F. M.: Fungal spores are transported long distances in smoke from biomass fires, Atmos. Environ., 38, 651-655, 2004.

Moura, M. A. L., Meixner, F. X., Trebs, I., Lyra, R. F. F., Andreae, M. O., and Filho, M. F. N.: Observational evidence of lake breezes at Balbina lake (Amazonas, Brazil) and their effect on ozone concentrations., Acta Amazonica, 34, 605-611, 2004.

Nakase, T.: Expanding world of ballistosporous yeasts: Distribution in the phyllosphere, systematics and phylogeny, Journal of General and Applied Microbiology, 46, 189-216, 2000.

Newson, R., Strachan, D., Corden, J., and Millington, W.: Fungal and other spore counts as predictors of admissions for asthma in the Trent region, Occupational and Environmental Medicine, 57, 786-792, 2000.

Nolte, C. G., Schauer, J. J., Cass, G. R., and Simoneit, B. R. T.: Highly polar organic compounds present in wood smoke and in the ambient atmosphere, Environ. Sci. Technol., 35, 1912-1919, 2001.

Novozhilova, M. I. and Popova, L. E.: Yeasts in marine environments, Antonie Van Leeuwenhoek, 35, D23-D24, 1969.

Pady, S. M., Peturson, B., and Green, G. J.: Arctic aerobiology. III. The presence of spores of cereal pathogens on slides exposed from airplanes in 1947, Phytopathology, 40, 632-641, 1950.

Page, R. M.: Sporangium discharge in Pilobolus: A photographic study, Science, 146, 925-927, 1964.

Pashynska, V., Vermeylen, R., Vas, G., Maenhaut, W., and Claeys, M.: Developement of a gas chromatographic/ion trap mass spectrometric method for the determination of levoglucosan and saccharidic compounds in atmospheric aerosols. Application to urban aerosols, J. Mass Spectrometry, 37, 1249-1257, 2002.

Pasteur, L.: Expériences relatives aux générations dites spontanées, Comptes rendus hebdomadaires des séances de l'Académie des sciences, 50, 303-307, 1860a.

Pasteur, L.: Suite à une précédente communication relative aux générations dites spontanées, Comptes rendus hebdomadaires des séances de l'Académie des sciences, 51, 675-678, 1860 b.

Paulitz, T. C.: Diurnal release of ascospores by Gibberella zeae in inoculated wheat plots, Plant Disease, 80, 674-678, 1996.

Penner, J. E.: Carbonaceous aerosols influencing atmospheric radiation: Black and organic carbon, in: Aerosol Forcing of Climate, edited by: Charlson, R. J. and Heintzenberg, J., Wiley and Sons, Chichester, 91-108, 1995.

Piepenbring, M., Hagedorn, G., and Oberwinkler, F.: Spore liberation and dispersal in smut fungi, Botanica Acta, 111, 444-460, 1998.

Pöschl, U.: Atmospheric aerosols: Composition, transformation, climate and health effects, Angewandte Chemie-International Edition, 44, 7520-7540, 2005.

Prados-Ligero, A. M., Melero-Vara, J. M., Corpas-Hervias, C., and Basallote-Ureba, M. J.: Relationships between weather variables, airborne spore concentrations and severity of leaf blight of garlic caused by Stemphylium vesicarium in Spain, European Journal of Plant Pathology, 109, 301-310, 2003.

Pringle, A., Baker, D. M., Platt, J. L., Wares, J. P., Latge, J. P., and Taylor, J. W.: Cryptic speciation in the cosmopolitan and clonal human pathogenic fungus Aspergillus fumigatus, Evolution, 59, 1886-1899, 2005a.

Pringle, A., Patek, S. N., Fischer, M., Stolze, J., and Money, N. P.: The captured launch of a ballistospore, Mycologia, 97, 866-871, 2005b.

Proctor, B. E.: The microbiology of the upper air. I., Proceedings of the American Academy of Arts and Sciences, 69, 314-340, 1934.

Prospero, J. M., Blades, E., Mathison, G., and Naidu, R.: Interhemispheric transport of viable fungi and bacteria from Africa to the Caribbean with soil dust, Aerobiologia, 21, 1-19, 2005.

Raes, F., Van Dingenen, R., Vignati, E., Wilson, J., Putaud, J. P., Seinfeld, J. H., and Adams, P.: Formation and cycling of aerosols in the global troposphere, Atmos. Environ., 34, 4215-4240, 2000.

Raupach, M. R., Marland, G., Ciais, P., Le Quere, C., Canadell, J. G., Klepper, G., and Field, C. B.: Global and regional drivers of accelerating CO2 emissions, Proceedings of the National Acadamy of Sciences, 104, 10 288-10 293, 2007.

Raynal, G.: Cinétique de la production d'ascospores de Sclerotinia trifoliorum Eriks en chambre de culture et en conditions climatiques naturelles. Incidences pratiques et épidémiologiques, Agronomie, 10, 561-572, 1990.

Ribes, J. A., Vanover-Sams, C. L., and Baker, D. J.: Zygomycetes in human desease, Clinical Microbiology Reviews, 13, 236-301, 2000.

Richardson, M. J.: The occurrence of airborne Didymella spores in Edinburgh, Mycological Research, 100, 213-216, 1996.

Rogers, L. A. and Meier, F. C.: The collection of micro-organisms above 36000 feet/The National Geographic Society - U. S. Army Air Corps Stratosphere Flight of 1935 in the Balloon "Explorer II", National Geographic Society - Contributed Technical Papers - Stratospheric Series, 2, 146-151, 1936.

Rossi, V., Giosue, S., and Bugiani, R.: Influence of air temperature on the release of ascospores of Venturia inaequalis, Journal of Phytopathology, 151, 50-58, 2003.

Rossman, A. Y.: Strategy for an all-taxa inventory of fungal biodiversity, in: Biodiversity and Terrestrial Ecosystems, edited by: Peng, C.-I. and Chou, C. H., Inst. Botany, Acad. Sinica Monograph Series, 14, 169-194, 1994.

Schadt, C. W., Martin, A. P., Lipson, D. A., and Schmidt, S. K.: Seasonal dynamics of previously unknown fungal lineages in tundra 
soils, Science, 301, 1359-1361, 2003.

Scheppergrell, W.: Airplane tests of hay fever pollen density in the upper air, Medical Journal and Record, 119, 185-189, 1924.

Schnell, R. G. and Vali, G.: Atmospheric ice nuclei from decomposing vegetation, Nature, 236, 163-165, 1972.

Scorzetti, G., Fell, J. W., Fonseca, A., and Statzell-Tallman, A.: Systematics of basidiomycetous yeasts: a comparison of large subunit D1/D2 and internal transcribed spacer rDNA regions, FEMS Yeast Research, 2, 495-517, 2002.

Seinfeld, J. H. and Pandis, S. N.: Atmospheric chemistry and physics: From air pollution to climate change, John Wiley, New York, 1998.

Shaner, G.: Effect of environment on fungal leaf blights of small grains, Annual Review of Phytopathology, 19, 273-296, 1981.

Simoneit, B. R. T. and Mazurek, M. A.: Organic matter of the troposphere-II. Natural background of biogenic lipid matter in aerosols over the rural western United States, Atmos. Environ., 16, 2139-2159, 1982.

Solomon, P. S., Waters, O. D. C., Jorgens, C. I., Lowe, R. G. T., Rechberger, J., Trengove, R. D. and Oliver, R. P.: Mannitol is required for asexual sporulation in the wheat pathogen Stagonospora nodorum (glume blotch), Biochemical Journal, 399, 231-239, 2006.

Stensvand, A., Amundsen, T., Semb, L., Gadoury, D. M., and Seem, R. C.: Discharge and dissemination of ascospores by Venturia inaequalis during dew, Plant Disease, 82, 761-764, 1998.

Stephen, E., Raftery, A. E., and Dowding, P.: Forecasting spore concentrations - a time-series approach, International Journal of Biometeorology, 34, 87-89, 1990.

Sterling, M., Rogers, C., and Levetin, E.: An evaluation of two methods used for microscopic analysis of airborne fungal spore concentrations from the Burkard Spore Trap, Aerobiologia, 15, 9-18, 1999.

Stier, P., J. Feichter, Kinne, S., Kloster, S., Vignati, E., Wilson, J., Ganzeveld, L., Tegen, I., Werner, M., Balkanski, Y., Schulz, M., Boucher, O., Minikin, A., and Petzold, A.: The aerosol-climate model ECHAM5-HAM, Atmos. Chem. Phys., 5, 1125-1156, 2005 ,

http://www.atmos-chem-phys.net/5/1125/2005/.

Strawbridge, K. B. and Snyder, B. J.: Planetary boundary layer height determination during Pacific 2001 using the advantage of a scanning lidar instrument, Atmos. Environ., 38, 5861-5871, 2004.

Sun, J. and Ariya, P. A.: Atmospheric organic and bio-aerosols as cloud condensation nuclei (CCN): A review, Atmos. Environ., 40, 795-820, 2006.

Suzuki, M. and Nakase, T.: The distribution of xylose in the cells of ballistosporous yeasts - Application of high performance liquid chromatography without derivatization to the analysis of xylose in whole cell hydrolysates, J. General Appl. Microbiol., 34, 95103, 1988.

Suzuki, Y., Kawakami, M., and Akasaka, K.: H-1 NMR application for characterizing water-soluble organic compounds in urban atmospheric particles, Environ. Sci. Technol., 35, 26562664, 2001.

Takashima, M. and Nakase, T.: Tilletiopsis derxii, Tilletiopsis oryzicola and Tilletiopsis penniseti, three new species of the ustilagionomycetous anamorphic genus Tilletiopsis isolated from leaves in Thailand, Antonie Van Leeuwenhoek, 80, 43-56, 2001.
Tate, K. G. and Wood, P. N.: Potential ascospore production and resulting blossom blight by Monilinia fructicola in unsprayed peach trees, New Zealand Journal of Crop and Horticultural Science, 28, 219-224, 2000.

Taylor, J. J.: The nature of the secondary conidia of Sporothrix schenkii, Mycopathologia et Mycologia Applicata, 41, 379-382, 1970.

Taylor, P. E., Flagan, R. C., Miguel, A. G., Valenta, R. and Glovsky, M. M.: Birch pollen rupture and the release of aerosols of respirable allergens, Clinical and Experimental Allergy, 34, 15911596, 2004.

Taylor, P. E. and Jonsson, H.: Thunderstorm asthma, Current Allergy and Asthma Reports, 4, 409-413, 2004.

Textor, C., Schulz, M., Guibert, S., Kinne, S., Balkanski, Y., Bauer, S., Berntsen, T., Berglen, T., Boucher, O., Chin, M., Dentener, F., Diehl, T., Easter, R., Feichter, H., Fillmore, D., Ghan, S., Ginoux, P., Gong, S., Kristjansson, J. E., Krol, M., Lauer, A., Lamarque, J. F., Liu, X., Montanaro, V., Myhre, G., Penner, J., Pitari, G., Reddy, S., Seland, O., Stier, P., Takemura, T., and Tie, X.: Analysis and quantification of the diversities of aerosol life cycles within AeroCom, Atmos. Chem. Phys., 6, 1777-1813, 2006, http://www.atmos-chem-phys.net/6/1777/2006/.

Timmer, L. W., Solel, Z., Gottwald, T. R., Ibanez, A. M., and Zitko, S. E.: Environmental factors affecting production, release, and field populations of conidia of Alternaria alternata, the cause of brown spot of citrus, Phytopathology, 88, 1218-1223, 1998.

Trail, F., Gaffoor, I., and Vogel, S.: Ejection mechanics and trajectory of the ascospores of Gibberella zeae (anamorph Fusarium graminearum), Fungal Genetics and Biology, 42, 528-533, 2005.

Trail, F., Xu, H. X., Loranger, R., and Gadoury, D.: Physiological and environmental aspects of ascospore discharge in Gibberella zeae (anamorph Fusarium graminearum), Mycologia, 94, 181189, 2002.

Treutlein, B. and Pöschl, U.: Measurement of primary biogenic aerosol particles with an ultraviolet aerodynamic particle sizer (UVAPS), Geophysical Research Abstracts, 9, 2007.

Troutt, C. and Levetin, E.: Correlation of spring spore concentrations and meteorological conditions in Tulsa, Oklahoma, International Journal of Biometeorology, 45, 64-74, 2001.

Turner, J. C. R. and Webster, J.: Mass and momentum-transfer on the small-scale - how do mushrooms shed their spores, Chemical Engineering Science, 46, 1145-1149, 1991.

Turner, J. C. R. and Webster, J.: Mushroom spores - The analysis of Buller's drop, Chemical Engineering Science, 50, 2359-2360, 1995.

Venette, J.: Sclerotinia spore formation, transport and infection., In: Proceedings of the Sclerotinia Workshop, 4-7, 1998.

Volkamer, R., Jimenez, J. L., San Martini, F., Dzepina, K., Zhang, Q., Salcedo, D., Molina, L. T., Worsnop, D. R., and Molina, M. J.: Secondary organic aerosol formation from anthropogenic air pollution: Rapid and higher than expected, Geophys. Res. Lett., 33, L17811, doi:10.1029/2006GL026899, 2006.

Wainwright, M., Wickramasinghe, N. C., Narlikar, J. V., and Rajaratnam, P.: Microorganisms cultured from stratospheric air samples obtained at $41 \mathrm{~km}$, FEMS Microbiol. Lett., 218, 161$165,2003$.

Warner, J. and Braun, P. G.: Discharge of Venturia inaequalis as- 
cospores during daytime and nighttime wetting periods in Ontario and Nova Scotia, Canadian Journal of Plant Pathology, 14, 315-321, 1992.

Watson, I. A. and DeSousa, C. N. A.: Long distance transport of spores of Puccinia graminis tritici in the southern hemisphere, Proceedings of The Linnean Society of New South Wales, 106, 311-321, 1983.

Webster, J., Davey, R. A., Smirnoff, N., Fricke, W., Hinde, P., Tomos, D. and Turner, J. C. R.: Mannitol and hexoses are components of Buller's drop, Mycological Research, 99, 833-838, 1995.

Webster, J., Davey, R. A., and Turner, J. C. R.: Vapor as the source of water in Buller's drop, Mycological Research, 93, 297-302, 1989.

Webster, J. and Weber, R. W. S.: Introduction to fungi, Cambridge University Press, Cambridge, 2007.

Weijman, A. C. M.: Carbohydrate composition and taxonomy of Geotrichum, Trichosporon and allied genera, Antonie Van Leeuwenhoek, 45, 119-127, 1979.

Wu, P. C., Tsai, J. C., Li, F. C., Lung, S. C., and Su, H. J.: Increased levels of ambient fungal spores in Taiwan are associated with dust events from China, Atmos. Environ., 38, 4879-4886,
2004.

Yamasato, K., Goto, S., Ohwada, K., Okuno, D., Araki, H., and Iizuka, H.: Yeasts from Pacific Ocean, Journal of General and Applied Microbiology, 20, 289-307, 1974.

Yeo, H.-G. and Kim, J.-H.: SPM and fungal spores in the ambient air of west Korea during the Asian dust (Yellow sand) period, Atmos. Environ., 36, 5437-5442, 2002.

Yttri, K. E., Dye, C., and Kiss, G.: Ambient aerosol concentrations of sugars and sugar-alcohols at four different sites in Norway, Atmos. Chem. Phys. Discuss., 7, 5769-5803, 2007, http://www.atmos-chem-phys-discuss.net/7/5769/2007/.

Zhang, Q. and Anastasio, C.: Free and combined amino compounds in atmospheric fine particles $\left(\mathrm{PM}_{2.5}\right)$ and fog waters from Northern California, Atmos. Environ., 37, 2247-2258, 2003.

Zhao, J. H., Bai, F. Y., Wang, Q. M., and Jia, J. H.: Sporobolomyces bannaensis, a novel ballistoconidium-forming yeast species in the Sporidiobolus lineage, International Journal of Systematic and Evolutionary Microbiology, 53, 2091-2093, 2003.

Zoppas, B. C. D. A., Valencia-Barrera, R. M., Duso, S. M. V., and Fernandez-Gonzalez, D.: Fungal spores prevalent in the aerosol of the city of Caxias do Sul, Rio Grande do Sul, Brazil, over a 2-year period (2001-2002), Aerobiologia, 22, 119-126, 2006 